\title{
Practices and Hydrological Effects of Road Water Harvesting in Northern Ethiopia: Towards Design of Multi-Functional Infrastructures
}

\author{
Kifle Woldearegay ${ }^{1 *}$, Frank van Steenbergen ${ }^{2}$, Berhane Grum $^{3}$, Taye Alemayehu ${ }^{2}$, \\ Kebede Manjur ${ }^{4}$ and Marta Agujetas Perez ${ }^{2}$ \\ ${ }^{1}$ School of Earth Sciences, Mekelle University, P.O. Box 231, Mekelle, Ethiopia \\ (*kiflewold@yahoo.com). \\ ${ }^{2}$ MetaMeta Research, Postelstraat 2, 5211 EA's-Hertogenbosch, The Netherlands. \\ ${ }^{3}$ School of Civil Engineering, Mekelle University, P.O. Box 3185, Mekelle, Ethiopia. \\ ${ }^{4}$ Department of Rural Development and Agricultural Extension, Mekelle University, P.O. \\ Box 231, Mekelle, Ethiopia.
}

\begin{abstract}
Infrastructure development (including roads and railways) are among the major investments in many countries in Africa. Road hydraulic structures (road side drainages, culverts and bridges) are mostly designed to discharge concentrated flow of water. Unmanaged water from roads could lead to erosion, flooding, water logging, siltation, and even landslides. To convert such problems into opportunities, road water harvesting (RWH) was systematically promoted in Tigray, northern Ethiopia, in the years 2014-2018. The method/approach used include: (i) participatory selection of RWH technologies, (ii) implementation of the technologies through community mobilization, and (iii) monitoring the hydrological effects/benefits of the interventions (mainly on soil moisture and groundwater levels). Results of the study revealed that harvesting water from road catchments is found to have several benefits: increase in groundwater recharge (enhancing infiltration and reducing flooding), improvement in soil moisture, and increase in availability of surface water in ponds/reservoirs. Road water harvesting/management was found to be an instrument to create resilience to rainfall variability and reduce the negative effects of water from roads; an opportunity which need to be promoted not only in water and land management but also in infrastructural development whereby multi-functional roads could be designed/constructed.
\end{abstract}

Keywords: Water management, Infrastructure, Climate resilience, Ethiopia.

\section{INTRODUCTION}

Africa is undertaking rapid socio-economic development including the constructions of roads and railway systems. Mobility and access are obviously the prime functions of road infrastructure and it is normally assumed that roads not only reduce poverty associated with spatial isolation and promote economic productivity but also enhance access to health and educational services (World Bank, 1994; Venables and Limao, 1999; Crawford et al., 2003; Pomfret, 2006; Bryceson et al., 2008; Ericson, 2008). Road development often change surface runoff patterns of landscapes and lead to concentrated flows of water. Various authors (e.g. Hatibu et al., 2000; Nyssen et al., 2002; Nissen-Petersen, 2006; García-Landarte et al., 2014; Woldearegay et al., 2015; Demenge et al., 2015; van Steenbergen et al., 2018) have reported on the negative effects of water from roads including: (a) flooding of farmlands, (b) 
development of gully erosion, (c) damage of dwelling houses, (d) flooding of hand-dug wells and ponds, and (e) environmental health problems from urban waste/storm runoff at downstream farmlands and urban communities.

Currently, most of the road constructions have no provision for the storage of runoff water generated from road drainage (Nissen-Petersen, 2006; Woldearegay et al., 2015; van Steenbergen et al., 2018). Collection of rainwater in upstream catchments (like roads and roadsides) can have both positive consequences for downstream areas which include (Riverson et al., 1991; Fishbein, 2001; Mahapa and Mashiri, 2001; IFPRI, 2005; de Grassi, 2000; Bouma et al., 2011; Woldearegay et al., 2015; Ngigi, 2003; Wilson, 2004; NissenPetersen, 2006; Demenge, 2011; Kubbinga, 2012): (a) increase in agricultural productivity and water availability, (b) larger diversity of production - in terms of crop choices, agroforestry, and small livestock, (c) improved environmental protection and conservation, (d) improved health and nutrition, (e) economic empowerment and social integration, and (f) new sources of income, for instance, from sand harvesting.

To promote road water harvesting/management, research and upscaling activities have been on-going in the years 2013/2014 to 2018 in Tigray region, northern Ethiopia. In this study, road water harvesting/management is defined as a technique and approach for collecting/ buffering water from road catchments (culverts, roadside ditches, bridges and road surfaces) for better use. Prior to the initiation of this research, different water harvesting practices (including water from roads) have been implemented in the region. However, the technologies were limited and implemented in isolated sites with no performance documentation/monitoring. This paper presents: (a) the methods/approaches followed to systematically introduce and upscale road water harvesting/management, (b) the different road water harvesting techniques implemented, (c) monitoring results on the hydrological effects of some of the implemented techniques (mainly on soil moisture and groundwater level) from 8 representative sites (Fig 1a) for the years 2013/2014 to 2018, and (d) scenarios/ approaches for promoting and upscaling RWH which takes into account the road-water interactions along a landscape continuum.

\section{RESEARCH METHOD}

The following approaches were followed to systematically introduce road water harvesting and to evaluate the hydrological effects/benefits.

- Assessment of issues related to water from roads: Survey was done on selected road routes in different parts of Tigray region, Ethiopia, with the objective of assessing the 
problems related to water from roads, the practices of road water management, and the perceptions of communities on the importance of water.

- Identification and designing methods of involvement of key stakeholders in implementation: The issue of road and water involves various sectors including the road, water, agriculture and environment. The following key stakeholders were identified and played key role in the systematic implementation and upscaling of road water harvesting: (a) Tigray Bureau of Agriculture and Rural Development, (b) Tigray Bureau of Road, Transport and Construction, (c) Tigray Bureau of Water Resources, (d) Relief Society of Tigray (REST), (e) Wukro Saint Mary College, and (f) local administrations and communities.

- Participatory planning with key stakeholders: Discussions and consultative meetings have been carried out with the key stakeholders to share ideas on: (a) the approaches and techniques to be used, (b) how to mobilize resources for implementation (including free labor/public mobilization as part of the watershed and moisture conservation activities), and (c) the parameters to be monitored to evaluate the performances of the interventions. Based on these discussions, different stakeholders have shared responsibilities to implement road water harvesting, and to evaluate/monitor the performances of the interventions.

- Capacity building and learning: Trainings on the concepts of road water management as well as experience sharing on previously implemented interventions were carried out. Capacity building involved experts, farmers, and decision/policy makers at various levels of the regional government.

- Implementation of locally adaptive and innovative $R W H$ practices: In almost all parts of Tigray region, different approaches and techniques of RWH were implemented systematically and the Tigray Bureau of Agriculture and Rural Development was leading the implementation part.

- Documentation and participatory performance evaluations of the implemented interventions: Implementation of RWH practices were done in various watersheds in the different Woredas/districts of the Tigray region. To document the practices of road water management, reconnaissance survey was done for about $700 \mathrm{Km}$ road (asphalt and gravel) which includes the following routes: (a) Mekelle-Adigrat-AdwaShire, (b) Mekelle- AbyiAdi- Adwa, (c) Mekelle-Adigudom- Hiwane, and (d) WukroAbreha Weatsbeha- Hawzien- Freweign road (Fig 1). 


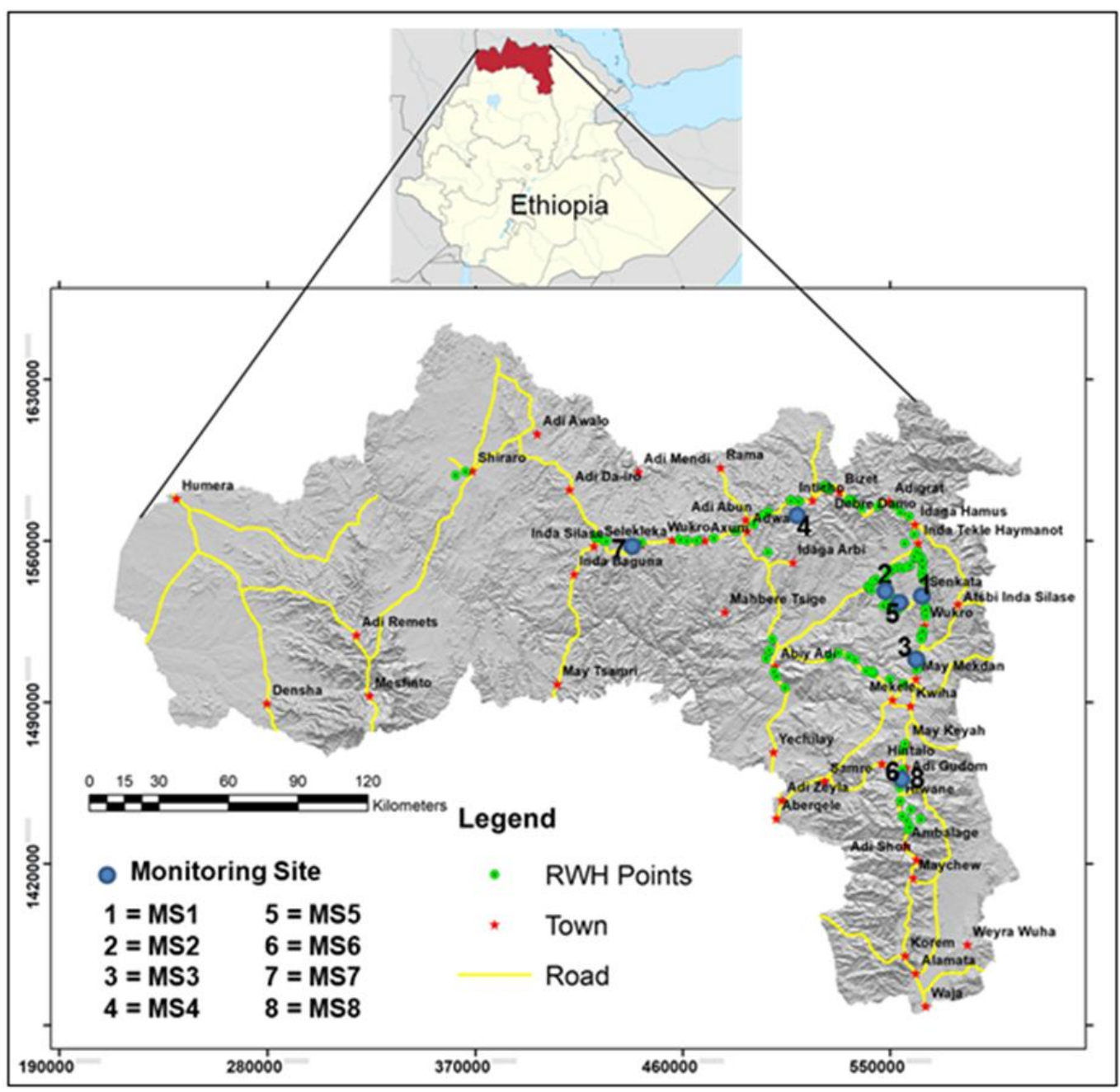

Figure 1. Location map of the different Road Water Harvesting (RWH) points inventoried along the selected routes, Tigray region, northern Ethiopia.

The approach/method used to evaluate the hydrological effects of the interventions includes:

- Site selection for monitoring: Though, road water harvesting was implemented throughout the Tigray region, hydrological monitoring was done only in 8 representative sites where baseline information was available.

- Defining the parameters for hydrological monitoring: Though, RWH has multiple benefits, this research focused on evaluation of the effects of interventions on soil moisture and groundwater levels in sites where baseline data was available for comparison, i.e. before and after the interventions.

- Rainfall data collection: Records of rainfall data from nearby hydro-meteorological stations of the Ethiopian National Meteorology Service Agency for the different years (ENMSA, 2018) was used for each of the monitoring sites.

- Soil moisture measurements: To evaluate the effects of interventions on soil moisture, measurements were carried out weekly for the months of September to November (June to 
September being rainy season) and compared with previous records. The months were selected because most of the crop failures in the region are due to shortage of moisture at maturation periods of the crops (mainly in the months September to October) (TBoARD, 2000). The in-situ soil moisture measurement involved soil sampling and laboratory analysis.

- Groundwater level measurement: The static groundwater level was measured in selected sites where previous data was available and measured downstream of the RWH structures on weekly basis. The monthly groundwater level is computed as the average of the weekly measurements. Measurement was designed to detect changes in groundwater levels after the interventions.

\section{GENERAL CHARACTERISTICS AND WATER HARVESTING PRACTICES IN TIGRAY}

\subsection{Climate and Topography}

The climate in Tigray is dominantly semi-arid with variable rainfall (both spatially and temporally). In the highland areas (elevation between $1500 \mathrm{~m}$ and $2300 \mathrm{~m}$ a.s.l) it is close to $900 \mathrm{~mm}$ and in the lowlands it varies from $500 \mathrm{~mm}$ (in eastern part) to $1200 \mathrm{~mm}$ (in western part) (ENMSA, 2018). Most of this falls in a spell of four months between June and September. The average annual temperature of the region varies from $10^{\circ} \mathrm{C}$ to $25^{\circ} \mathrm{C}$. Topographically, the region is comprised of flat valley floors, rolling hills, cliffs, and plateaus. The altitude ranges from about $500 \mathrm{~m}$ to about $3900 \mathrm{~m}$ a.m.s.l.

\subsection{Geohydrology of Tigray Region}

Major soil and rock types (from oldest to youngest) present in Tigray are (EGS, 2002): metamorphic rocks (Tsaliet and Tambian Groups), Enticho Sandstone, Edga Arbi Tillite, Adigrat Sandstone, Antalo Limestone, Agula Shale, Ambaradom Sandstone, Intrusive rocks, Trap volcanics, and alluvial soils. The geohydrology is dominantly characterized by shallow unconfined aquifers, with limited areas characterized by deep alluvial aquifers (mainly Raya Valley) and fractured aquifers (EGS, 2002; Woldearegay et al., 2006; Woldearegay and van Steenbergen, 2015). In many flat/gentle terrains of Tigray, the top weathered zone (depth not exceeding 40m) has higher permeability (EGS, 2002; Woldearegay and van Steenbergen, 2015) whereby through proper geohydrological evaluation, shallow groundwater resources development could play a critical role in small scale irrigation and local water supply.

\subsection{Land Restoration and Water Harvesting Practices}

In order to ensure food and water security at household level in Ethiopia in general and northern part of the country in particular, massive landscape restoration efforts have been implemented since 1970's. Different technologies that are appropriate to specific landscapes 
were selected and implemented (Woldearegay et al., 2018): (a) soil and water conservation measures like deep trenches, bunds, percolation pit/ponds, and afforestation in the upper parts of the watershed; (b) gully rehabilitation/stabilization works through construction of checkdams (sediment storage and/or water harvesting), gully reshaping as well as construction of percolation ponds and check-dam ponds at lower and middle levels of the watershed; (c) soil moisture enhancement (e.g. trenches and soil bunds) as well as soil improvement techniques like mulching at lower parts of the watershed mainly at farm lands; and (d) area exclosures and implementation of biological measures along bunds (within the farm lands) and along gullies as part of stabilization works. In addition, different types of water harvesting structures (such as dams, river diversions, ponds, shallow groundwater wells, etc.) have been constructed and small-scale irrigation is promoted in the region over the last years.

Several studies (e.g. Woldearegay et al., 2006; Woldearegay and van Steenbergen, 2015; MWE, 2012; Villholth, 2013) show that shallow groundwater irrigation has increased over the years and soil and water conservation practices in the region has enhanced groundwater levels and quality. Construction of surface water harvesting structures such as dams, have enhanced groundwater recharge (Woldearegay et al., 2006; Berhane et al., 2016) and provided an opportunity for conjunctive use of surface and groundwater. Despite all the land restoration efforts, road development has been contributing to land degradation (TBoARD, 2008, 2012). Various researchers (e.g. Woldearegay, 2005; Nyssen et al., 2002) have indicated the linkages between road development and gully erosion as well as landslides. Though, some road water harvesting practices were implemented in different locations in Tigray earlier, a systematic approach of intervention with proper planning and documentation is done only recently.

\section{RESULTS AND DISCUSION}

\subsection{Road Water Harvesting Techniques}

As part of the community based watershed management and moisture conservation activities, different road water harvesting techniques have been implemented. To assess the types of technologies implemented, about $700 \mathrm{Km}$ road survey was carried out. Though, road water harvesting is implemented in almost all parts of Tigray region and in all types of roads (from highways to foot paths), this study has focused on the main highways (both asphalt and gravel roads) with the selected routes as examples (Fig 1). A total of 182RWH sites have been assessed (Fig 2). 


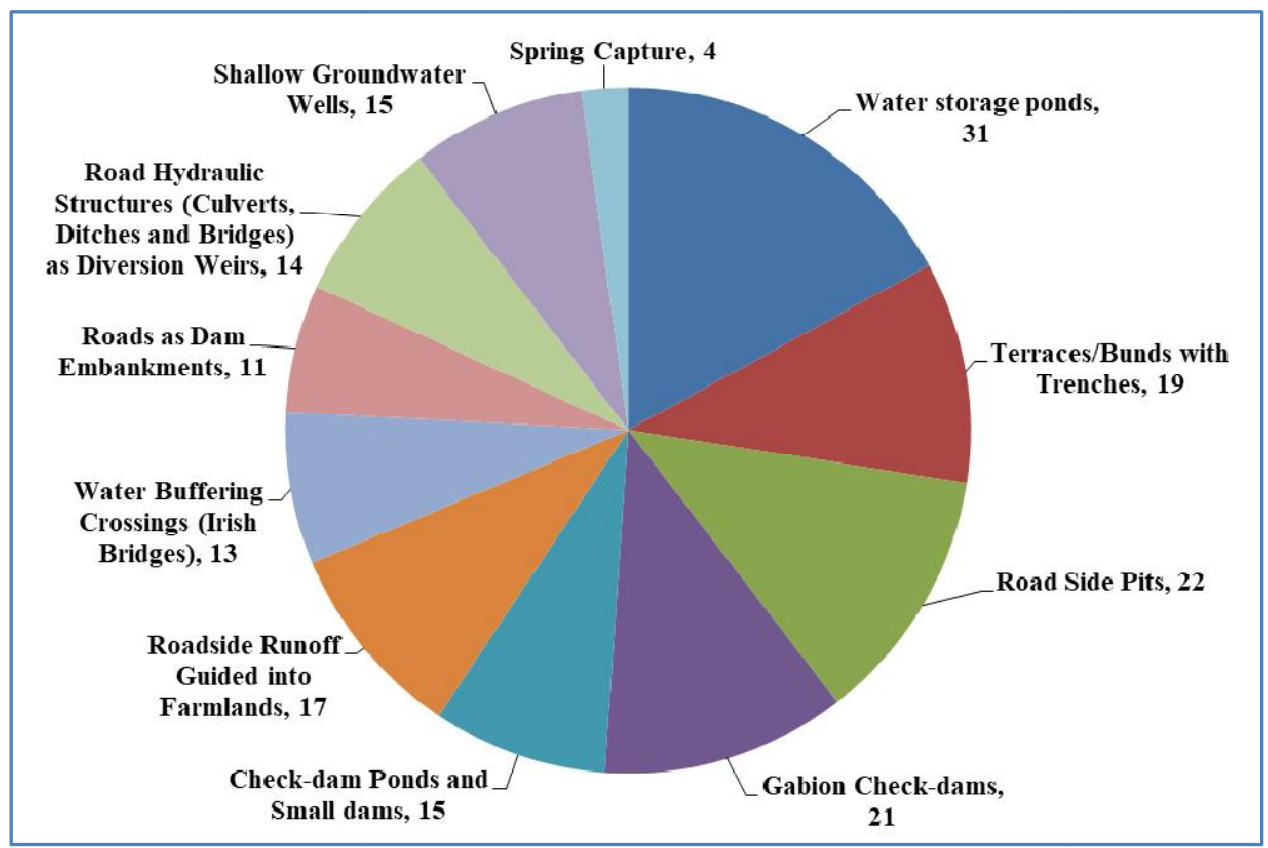

Figure 2. Types of RWH technologies and numbers of sites assessed along the surveyed roads, Northern Ethiopia.

The main types of RWH technologies implemented in the region are discussed below.

\subsubsection{Water Storage Ponds}

Ponds vary in size from $1 \mathrm{~m}^{2}$ to about 2-5 ha in area and may be permanent or seasonal, manmade or naturally created (Pond Conservation Group, 1993; Collinson et al., 1995; Biggs et al., 2007). Water from culverts, roadside ditches and bridges are being channeled into water storage ponds. A total of 31 ponds have been evaluated along the selected routes and two types have been recorded: excavated water storage ponds (e.g. Plate 1a), and borrow pits converted into water storage structures (e.g. Plate 1b). The size of these water storage structures vary in size ranging from $10 \mathrm{~m}^{3}$ to $5000 \mathrm{~m}^{3}$ storage capacity. These ponds are used as surface water storage for livestock watering, household use (washing) and small-scale irrigation as well as for groundwater recharge. Some of the challenges with ponds include: (a) siltation in 12 sites (where there was no sediment trap), (b) excessive seepage/leakage of water in 3 sites, (c) evaporation from open ponds in all the sites, (d) safety concerns (human and animal) for 28 ponds (non-fenced), and (e) spillway design problem (missing in 13 sites).

\subsubsection{Terraces / Bunds with Trenches}

Terraces are earth embankments constructed across the slope to intercept surface runoff, convey it to a stable outlet at a non-erosive velocity and shorten slope length (Morgan, 1995). Terraces with deep trenches are among the most effective soil and water conservation 
physical structures which are commonly used to enhance soil moisture, reduce runoff/ erosion, and increase groundwater recharge in northern Ethiopia (Tamene et al., 2016; Grum et al., 2017; Woldearegay et al., 2018). A total of 19 sites with such interventions are assessed. Though, these techniques are previously applied for land management interventions, in recent years, water from roads (culverts, roadside ditches and bridges) is being channeled into such structures for enhancing soil moisture, reducing flooding of farm lands, and recharging groundwater (e.g. Plate 2a, b).

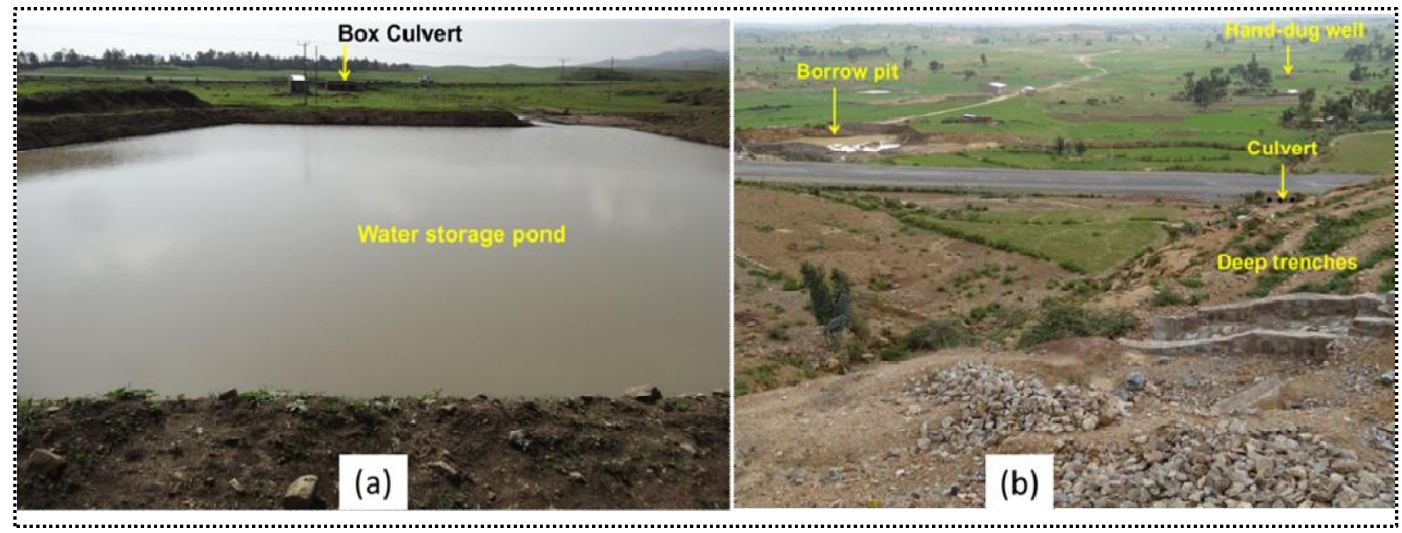

Plate 1. Use of ponds to harvest water from roads in northern Ethiopia: (a) excavated ponds, and (b) borrow pit converted into water storage in Tigray, Ethiopia.

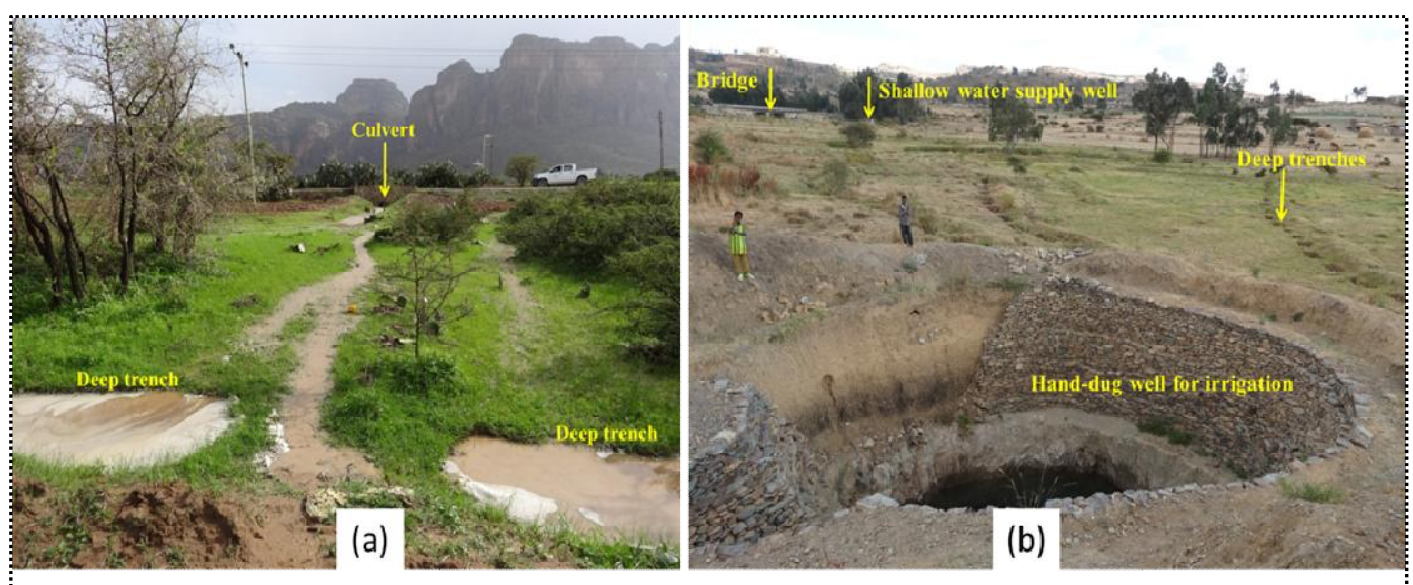

Plate 2. Water from roads (culverts, bridges) is channeled into series of deep trenches for enhancing soil moisture, reducing flooding and recharging groundwater in Ethiopia: (a) water from a culvert channeled into a deep trench, and (b) water from a bridge is channeled into series of deep trenches for enhancing shallow groundwater (for water supply and irrigation use).

\subsubsection{Road Side Pits}

In order to enhance soil moisture of farm lands, local communities have constructed pits along road sides. From evaluation of 22 sites, the shapes and sizes of the pits were found to be variable with maximum size of $2.5 \mathrm{~m}$ length* $1.5 \mathrm{~m}$ width and $0.5 \mathrm{~m}$ depth (e.g. Plate $3 \mathrm{a}, \mathrm{b}$ ). 
Some of the challenges observed with road side pits include: (a) water filled pits have caused water logging in 12 sites, (b) siltation problems of pits in 8 sites which required yearly maintenance, and (c) road safety in 5 sites as they were within the road reserve and no fence/protection.

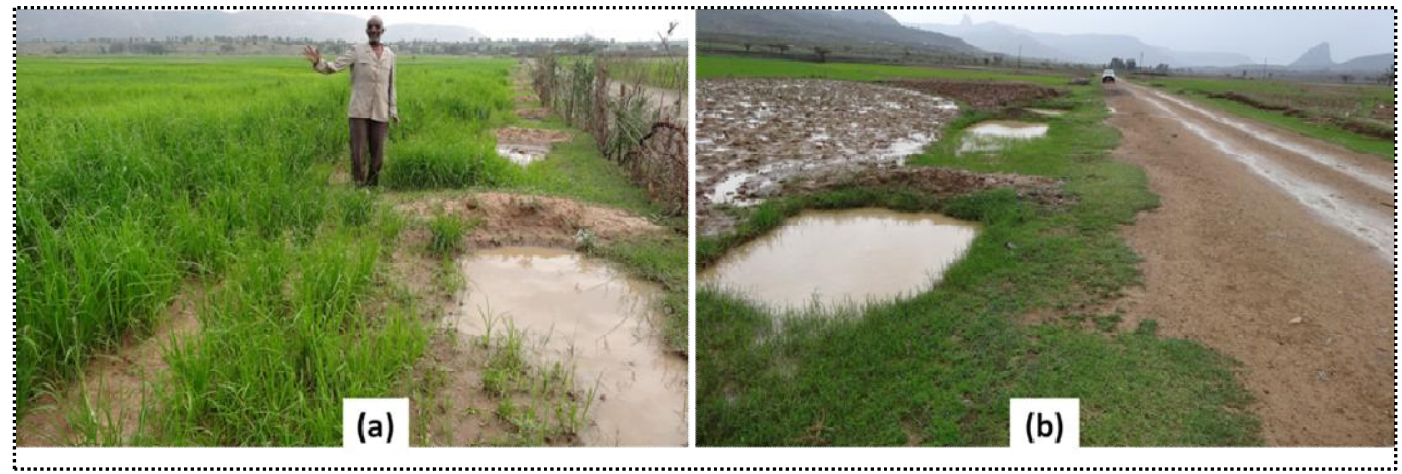

Plate 3. Use of roadside pits to enhance soil moisture and groundwater recharge in northern Ethiopia: (a) middle period of crop growth, and (b) early period crop growth.

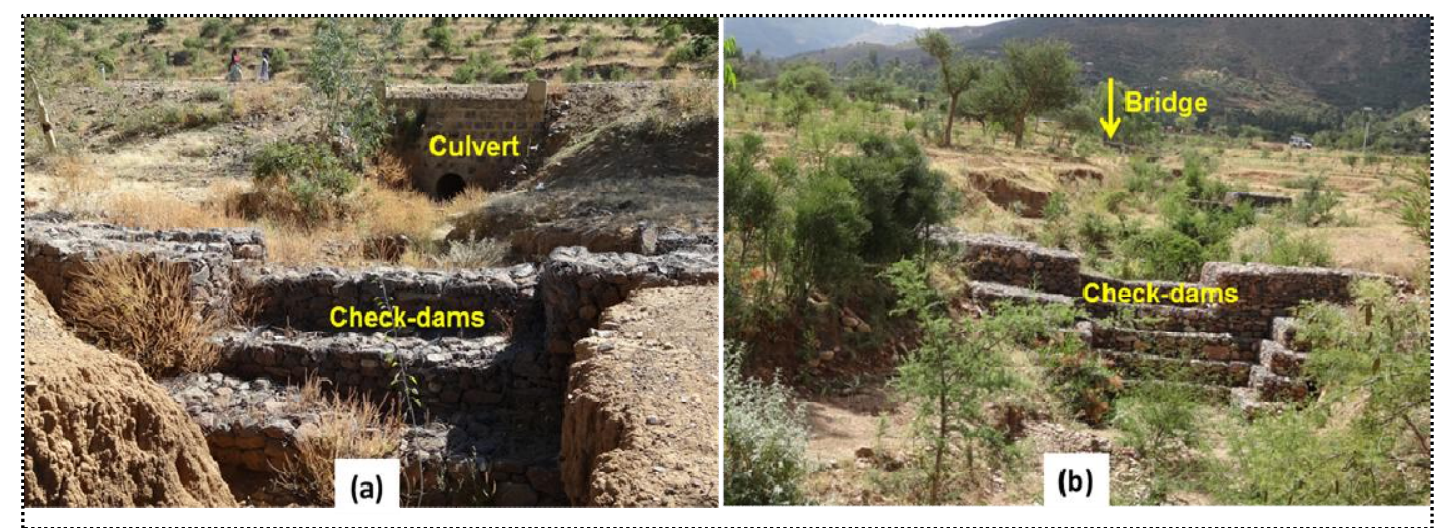

Plate 4. Use of gabion check-dams to manage water from roads in northern Ethiopia: (a) channeling water from a pipe culvert into a gabion check-dam, and (b) channeling water from a bridge into series of gabion check-dams for groundwater recharge.

\subsubsection{Gabion Check-dams}

These are small barriers constructed of rocks, or other materials placed across the flow and anchored into the bottom and sides of the channel and produce upstream and downstream hydrological effects (Polyakov et al., 2014). They modify water and sediment transport by impounding storm flow, reducing its velocity and peak rate, decreasing channel slope, and allowing more time for infiltration and sediment settling (Mishra et al., 2007). Check-dam construction is a common gully treatment technique in northern Ethiopia. In recent years, this technology is linked with road water management. Evaluations of a total of 21 sites show that water from culvert, bridges and road side ditches is channeled into gabion check dams for reducing downstream erosion and enhancing groundwater recharge (e.g. Plate 4). 


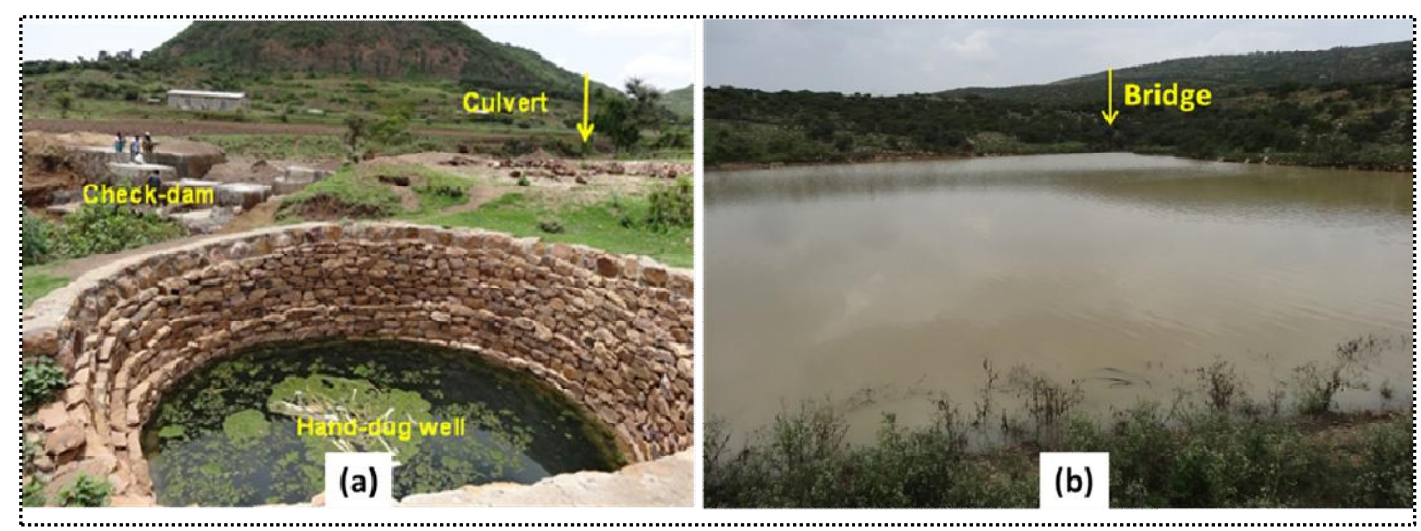

Plate 5. Water from road catchments is channeled into water storage structures for surface water harvesting and groundwater recharge in northern Ethiopia: (a) water from a culvert is stored in a check-dam pond, and (b) small dam is used to store water from a bridge.

\subsubsection{Check-dam Ponds and Small dams}

In many areas in Tigray region, gully erosion has left deeply incised streams which could be converted into water storage systems. A total of 15 sites were assessed to evaluate the hydrological effects of check-dams ponds. It is becoming a common practice that water from roads (culverts, roadside ditches, and bridges) is being stored in check-dam ponds for surface water storage and groundwater recharge (e.g. Plate 5a). In areas with large catchment size, water from bridges and culverts are stored in small dams (e.g. Plate 5b). Some of the challenges observed include: (a) siltation problems in 5 sites, (b) abutment erosion in 3 sites, (c) excessive seepage/leakage of water in 4 sites, (c) evaporation from open check-dam ponds in all sites, and (d) safety concerns (human and animal) in all sites.

\subsubsection{Roadside Runoff Guided into Farmlands}

Diverting runoff (from road sides and culverts) into farm lands (e.g. Plate 6) is one of the technologies implemented in areas where the rainfall is not high and the flood is limited. Assessments of a total of 17 sites revealed that such interventions have an effect on enhancing soil moisture: an approach which enhances availability of water for crop production. Assessments of these RWH technologies show some problems: (a) direct runoff from roadsides have caused flooding of downstream areas during heavy rainfall in 6 sites as it was difficult to control the flood as it is associated with short unpredictable rainfall events, and (b) water logging in 4 sites which are characterized by flat areas but dominated by less permeable soil/rock.

\subsubsection{Water Buffering Crossings (Irish Bridges)}

Irish bridges have multiple functions: allow road traffic to cross dry river beds and act as sand 
dams, trapping sediments behind them and creating small local aquifers that can store and retain water (Neal, 2012). Assessments of 13 sites show, as part of up scaling, several hand dug wells are developed upstream of Irish bridges for water supply and small-scale irrigation in northern Ethiopia (e.g. Plate 7). One of the problems with Irish bridges is safety issues during flood time and slippery nature of the road (due to algal materials).

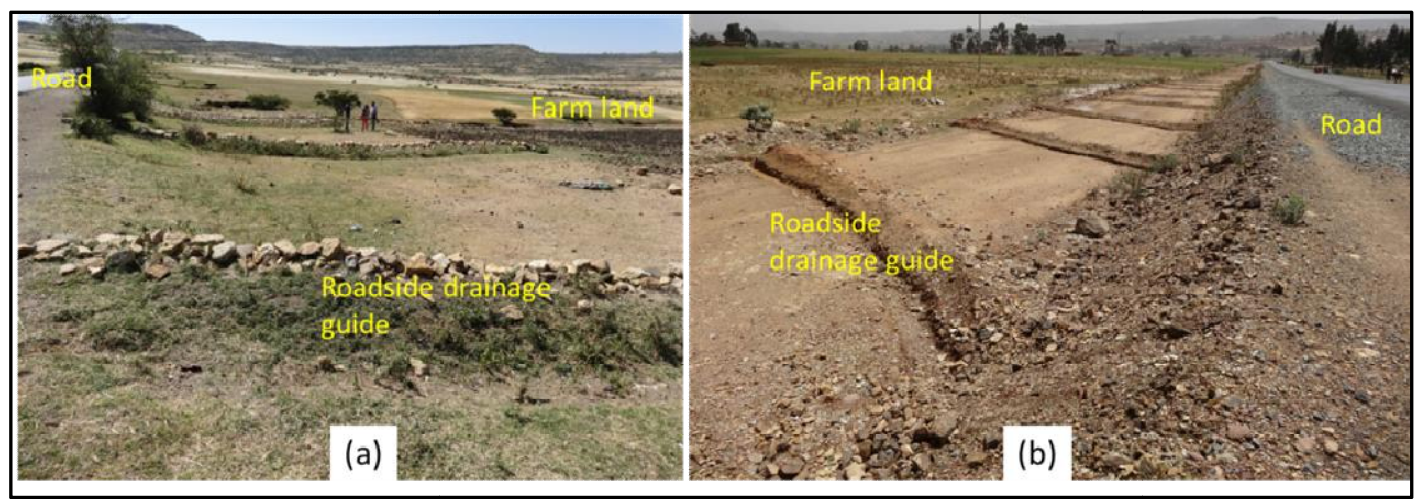

Plate 6. Road side runoff guided into farm lands as part of moisture conservation in northern Ethiopia: (a) runoff guide with stone bunds, and (b) runoff guide with earth bunds.

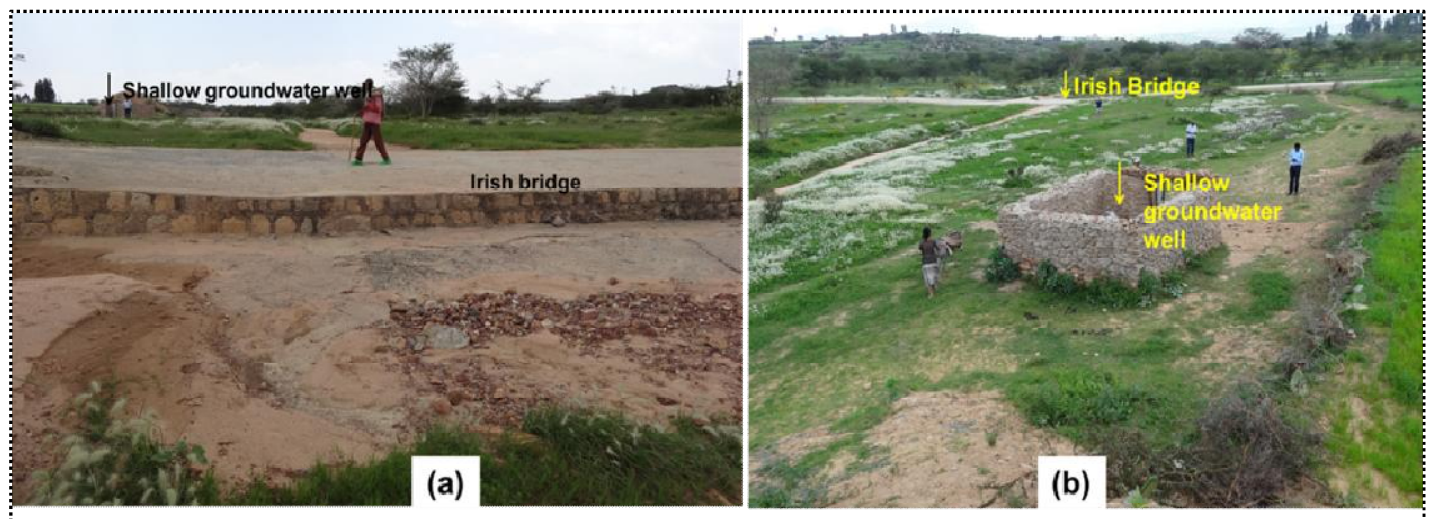

Plate 7. A shallow groundwater well (for water supply) developed at upstream of an Irish bridge in northern Ethiopia (a) Upstream view and (b) downstream view.

\subsubsection{Roads as Dam Embankments}

In places where raised road embankments are build it is common to observe water logging at upstream and/or at downstream of roads. Assessments of a total of 11 sites show that in suitable locations where the issue of space for water storage is not a problem, it is possible to design and construct road embankments to act as water storage dams. Such structures are important for surface water storage and groundwater recharge (e.g. Plate 8). Some of the challenges observed with such structures include: (a) siltation in 5 sites with no upstream watershed treatment, (b) slope instability of road embankment in 2 sites, (c) evaporation from open reservoir in all sites, and (d) safety concerns (human and animal) if not protected/ 
fenced. Road embankments designed to act as water storage structures need to be given special attention with regard to the type of construction material to be used and the slope of the road embankments as well as the foundation conditions because these structures are typically acting as small dams as well as road embankments.

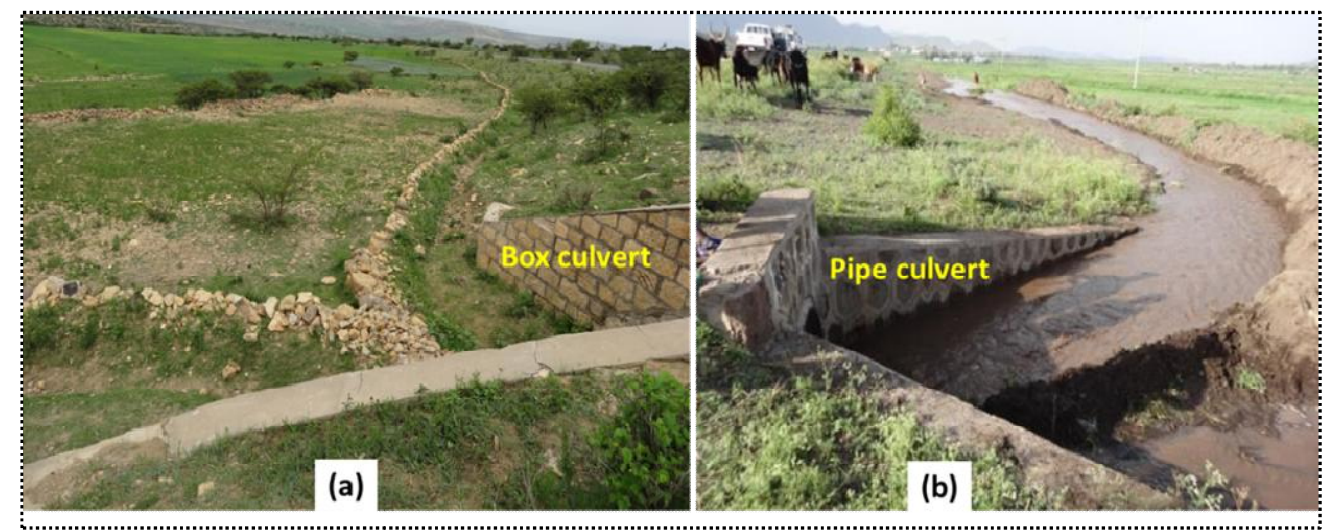

Plate 8. Roads used as dam embankments to store water and sediment in northern Ethiopia: (a) pond used to store sediment (used for sand mining) and water storage (for multiple use including groundwater recharge, surface water storage, etc), and (b) pond used to store water for small-scale irrigation and groundwater recharge.

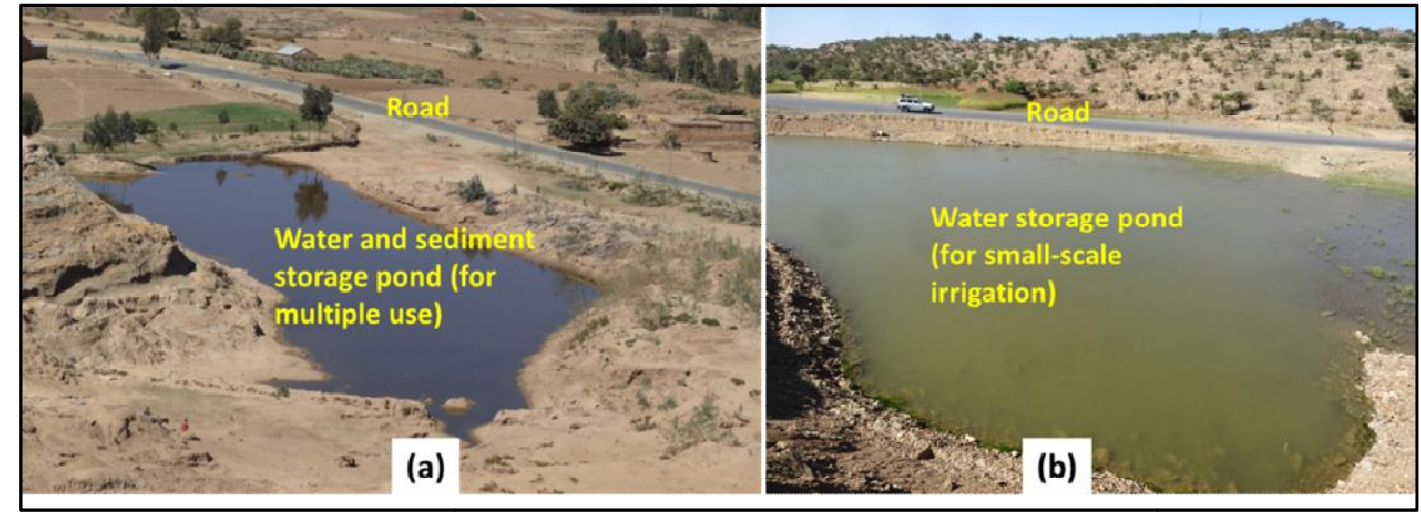

Plate 9. Examples of culverts being used as diversion structures to channel water into farm lands in northern Ethiopia: (a) water from a box culvert is diverted into traditional canals and channeled into farm lands, and (b) water from a pipe culvert is guided into traditional canals as spate systems.

\subsubsection{Road Hydraulic Structures (Culverts, Ditches and Bridges) as Diversion Weirs}

The different road hydraulic structures like culverts, roadside ditches, and bridges are water conveyance systems. A total of 14 sites with such interventions have been assessed whereby such hydraulic structures are used as diversion structures to channel water into farm lands (e.g. Plate 9) or into suitable storage locations. Some of the challenges observed include the following: (a) direct runoff from roadside have caused flooding of farm lands in 5 sites during heavy rainfall leading to water logging and siltation of farm lands, (b) difficult to 
control the flood as it is associated with short unpredictable rainfall events, (c) frequent maintenance of water conveyance systems that guide water from road sides into farm lands.

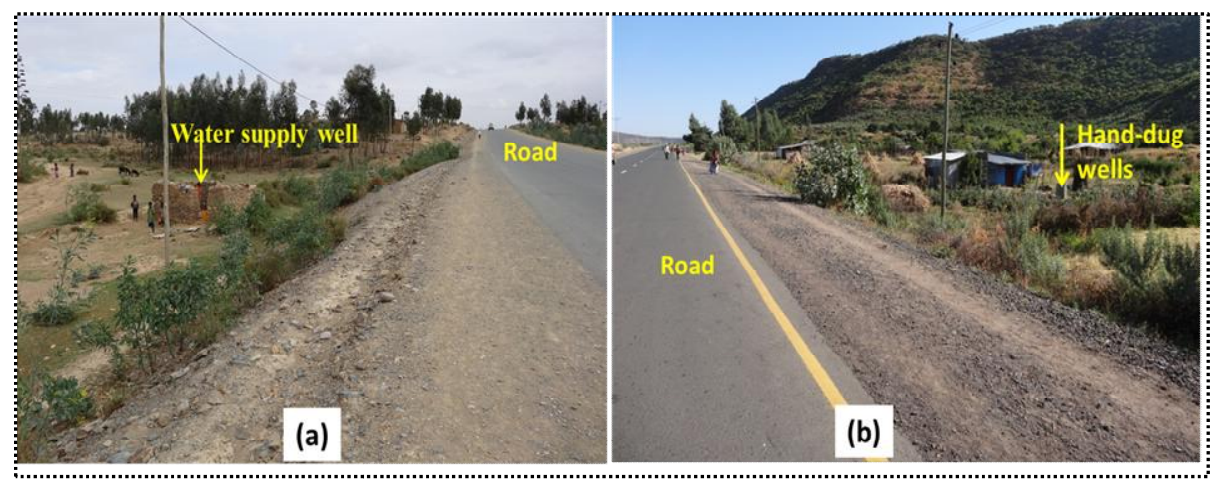

Plate 10. Upgrading of the road has resulted in an increase in groundwater availability due to recharge along roads in northern Ethiopia: (a) well at downstream of road, and (b) well at upstream of the road.

\subsubsection{Shallow Groundwater Wells}

Road development has an effect not only on surface hydrology but also on groundwater movements because of the differential compaction during construction and operation. Road transect survey in Tigray (Woldearegay et al., 2015) has revealed different scenarios in relation to the effects of road construction on downslope/downstream-upslope/upstream groundwater conditions. Evaluations of a total of 15 sites show a difference in groundwater regime at upslope and downslope areas of roads; groundwater wells were developed for small-scale irrigation (e.g. Plate 10b). In other areas, after upgrading of a road, the embankment was raised to about $2 \mathrm{~m}$ above original ground level (e.g. Plate 10a) and because of ponding of water at upstream, groundwater wells has been enhanced at downstream. Development of shallow groundwater wells is possible at upslope of the roads and/or in areas where buffering of groundwater is expected.

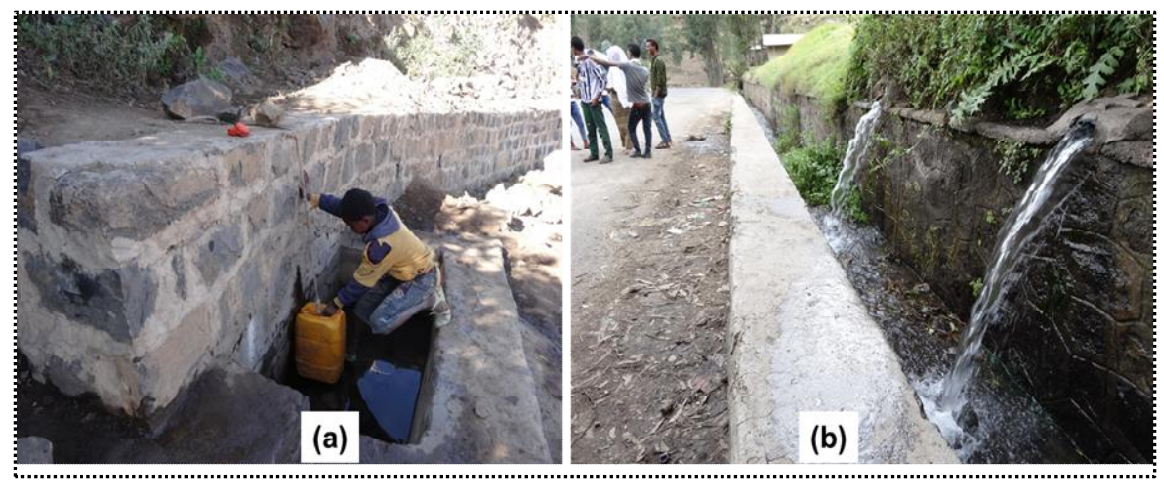

Plate 11. Spring developed from a road cut in northern Ethiopia: (a) for rural water supply, and (b) for small-scale irrigation purpose. 


\subsubsection{Spring Capture}

Road development in mountainous and hilly areas often involves road cuts which could open up springs. Though, not commonly used, evaluations of 4 sites show that spring capture from road cuts is practiced in Tigray for water supply purposes (e.g. Plate 11a) and small-scale irrigation (Plate 11b). Design of proper spring capture structures could enhance the availability of water and stabilize slopes as it acts as sub-surface water drainage.

\subsection{Hydrological Effects of Road Water Harvesting}

In order to evaluate the hydrological effects of different RWH, monitoring was carried out in 8 sites for the period 2013/2014 to 2018 . These sites were selected because of the availability of groundwater level and soil moisture data before the interventions. Results of the hydrological monitoring are discussed below.

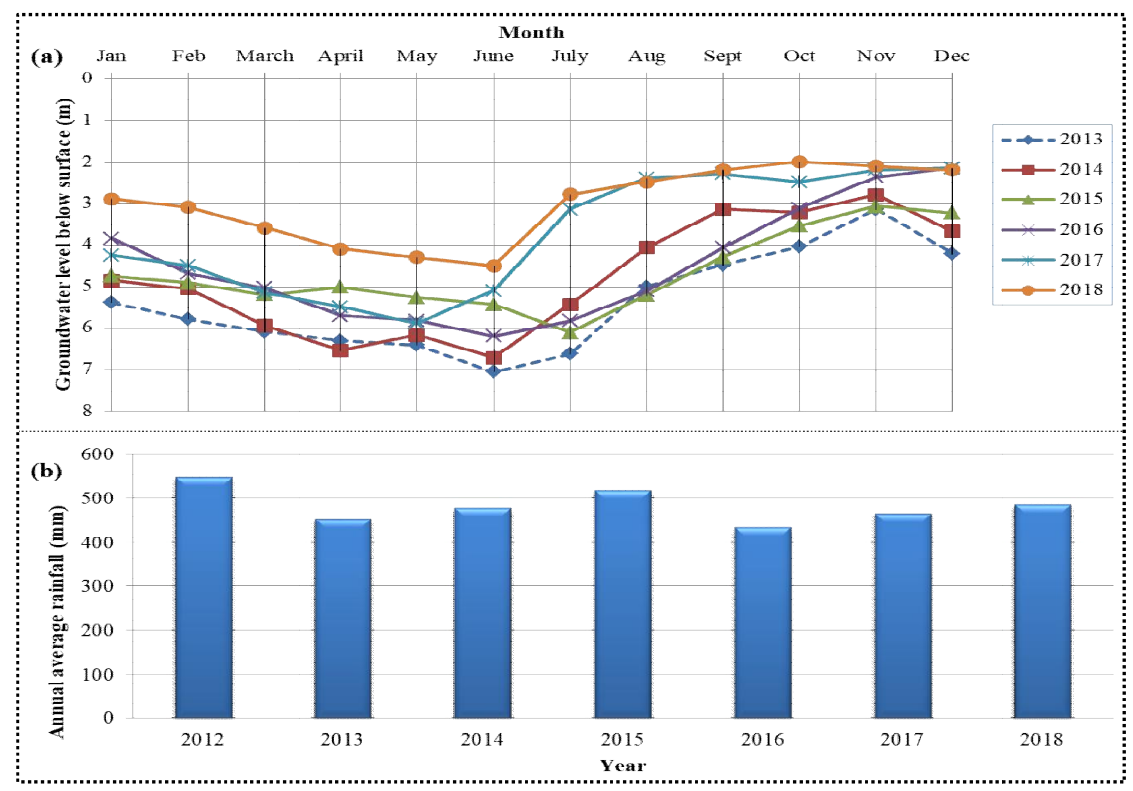

Figure 3. (a) Groundwater fluctuation in Freweign area, Tigray, Ethiopia. The well is located at downstream of a borrow pit converted into a percolation pond. The borrow pit was converted into a pond on July 2014 and monitoring was done for the whole period 2013 to 2018. Three additional water storage ponds were constructed at the end of 2016 for groundwater recharge purpose. (b) Rainfall distribution for Freweign area for the year 2012 to 2018 (ENMSA, 2018).

\subsubsection{Effects of Converting Borrow Pit into a Water Storage Pond (MS1)}

One of the monitoring site (MS1) (Fig 1) is Freweign area where storm runoff was causing flooding of downstream farmlands, dwelling houses and water storage structures. To address these issues, borrow pit (Plate 1b) was converted into a water storage pond for two reasons: to reduce the effects of flooding from the town, and to enhance groundwater recharge at downstream areas. Monthly monitoring of the water level of a hand-dug well at downstream 
of the borrow pit has shown an improvements in the groundwater level as compared to the records of previous years of the same period (Fig 3a). Flooding of the downstream areas has also been controlled as a result of the conversion of the borrow pit into a water storage pond. Understanding the benefits, more ponds were constructed at the end of 2016 and in the year 2018 the shallow groundwater has improved to a depth not more than $4.5 \mathrm{~m}$. Despite rainfall variability over the years (Fig 3b), the groundwater level has improved after the intervention because of the recharge from the borrow pit which is converted into a water storage pond.

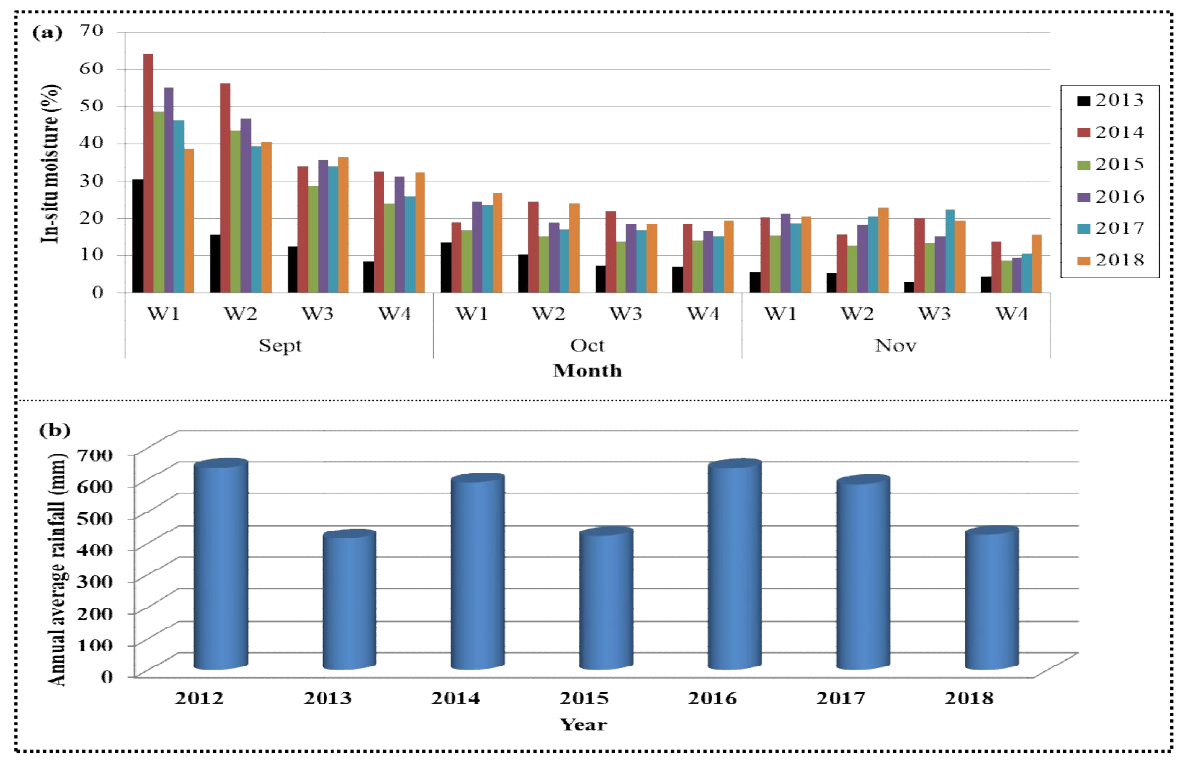

Figure4. (a) In-situ moisture distribution in soils which are sandy clay to loam soils (before and after the construction of deep trenches at downstream of culverts in Megab area, Tigray, Ethiopia. Construction of the deep trench was done on June 2014. Monitoring was done for the period September-November for the years 2013 to 2016. (W1= Week one; W2=Week two; W3=Week three and W4=Week four). (b) Rainfall distribution for Megeb area for the year 2012 to 2018 (ENMSA, 2018).

\subsubsection{Effects of Diverting Water from Culverts into Deep Trenches (MS2)}

As discussed in the preceding sections, one of the road water harvesting technology which is commonly implemented as part of the moisture conservation practice in Tigray is diverting water from road sides, culverts, and bridges into percolation systems (such as trenches, pits). As a typical example of such intervention, hydrological monitoring was carried out on site MS2 (Fig 1). Measurement of the in-situ moisture of the soils around the trenches shows an increase in moisture content of the soil (up to/ over 100\%) as compared to the previous year of the same season (Fig 4a). Though, there has been rainfall variability over the years (Fig $4 \mathrm{~b})$, the soil moisture was found to be higher after the intervention than before. 


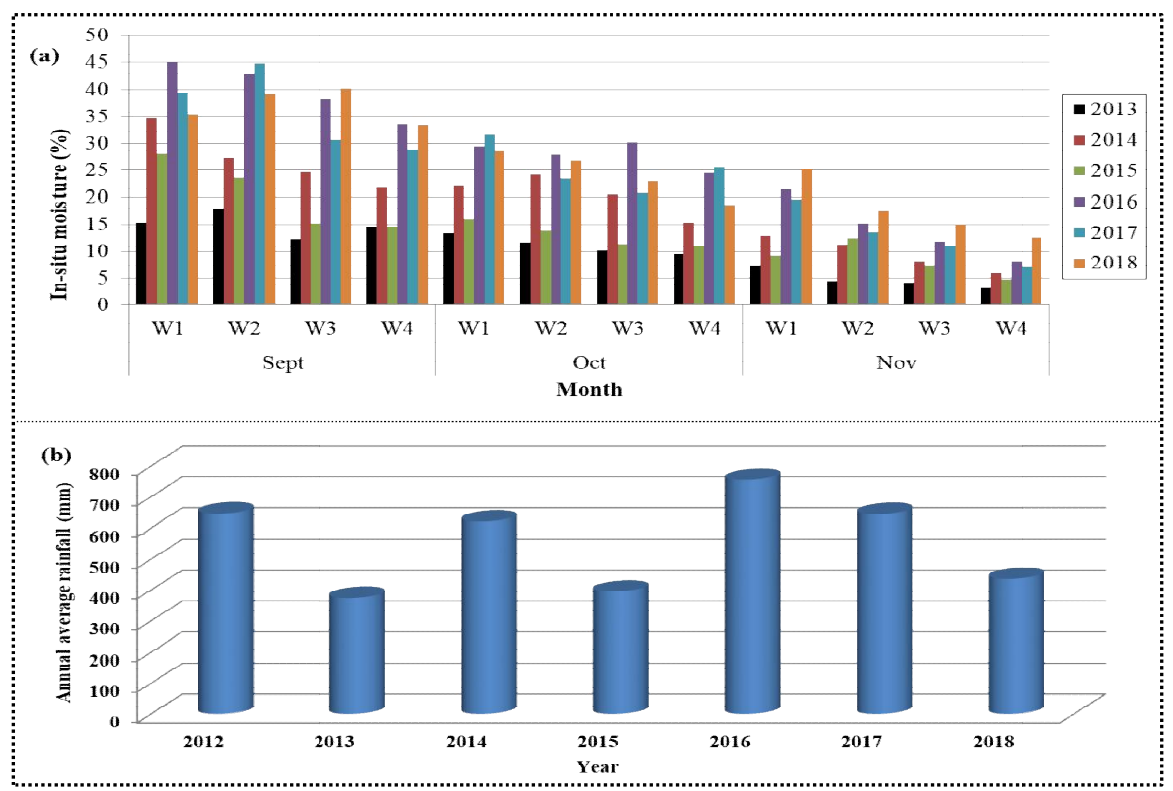

Figure 5. (a) In-situ moisture distribution in soils (before and after the construction of structures that divert runoff from culverts into farm lands along the Mekelle-Wukro road (Kihen), Tigray, Ethiopia. Construction of the diversion structures was done on May-June 2014. Monitoring was done for the period September-November for the years 2013 to 2018. (W1= Week one; W2=Week two; W3=Week three and W4=Week four). (b) Rainfall distribution for Kihen area for the year 2012 to 2018 (ENMSA, 2018).

\subsubsection{Effects of Road Side Pits on Soil Moisture in Different Soil Types}

Excavation of pits at road sides is one of the technologies implemented to manage water from roads with the purpose of enhancing soil moisture close to roads. Assuming that different soil types will respond differently (in terms of soil moisture) to the interventions, sites with three different soil types were monitored in the period 2013-2018.

\subsubsection{Effects of Road Side Pits on Soil Moisture in Clayey Silt Soils (MS4)}

Monitoring was done to evaluate the changes in moisture contents of clayey silt soils before and after the construction of the pits (MS4). Results of monitoring (Fig 6a) show that the moisture content of the soils has improved by up to $80 \%$ after the intervention when compared to the same season before the intervention. Comparison of with rainfall (Fig 6b), shows that despite low rainfall in these years, the moisture content after the intervention remained higher than before the intervention.

\subsubsection{Effects of road side pits on soil moisture in clayey sand to loam soil (MS5)}

Monitoring was done to evaluate the moisture contents of the sandy clay to loam soils before and after the construction of the pits (MS5). Results of monitoring (Fig 7) show that the 
moisture content of the soils has improved by $90 \%$ after the intervention when compared to the same season before the intervention.

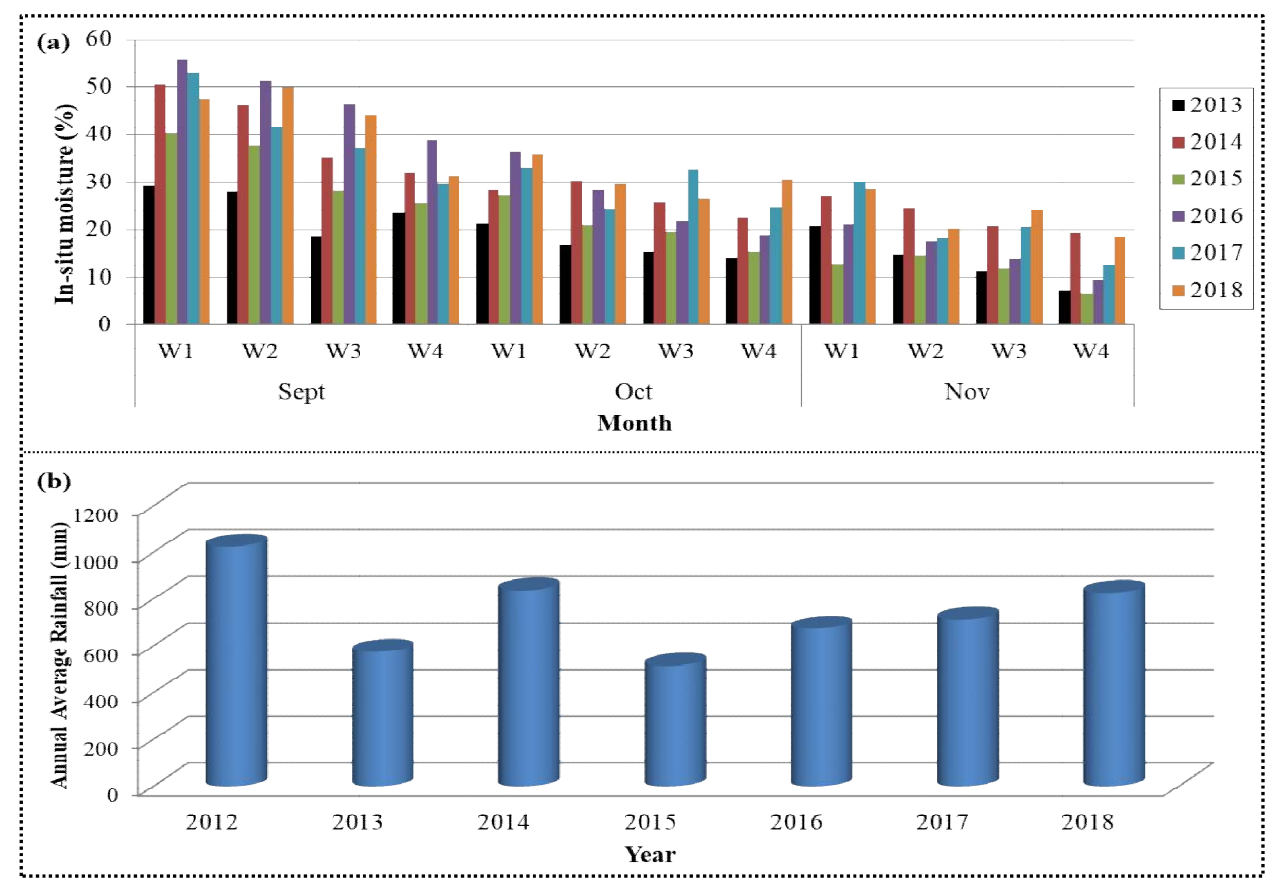

Figure 6 a) In-situ moisture distribution in soils (before and after the construction of road side pits in Feresmay area, Tigray, Ethiopia. Construction of the road side pits was done on May-June 2014. Monitoring was done for the period September-November for the years 2013 to 2016. (W1= Week one; W2=Week two; W3=Week three and W4=Week four); b) Rainfall distribution for Feresmay area for the year 2012 to 2018 (ENMSA, 2018).

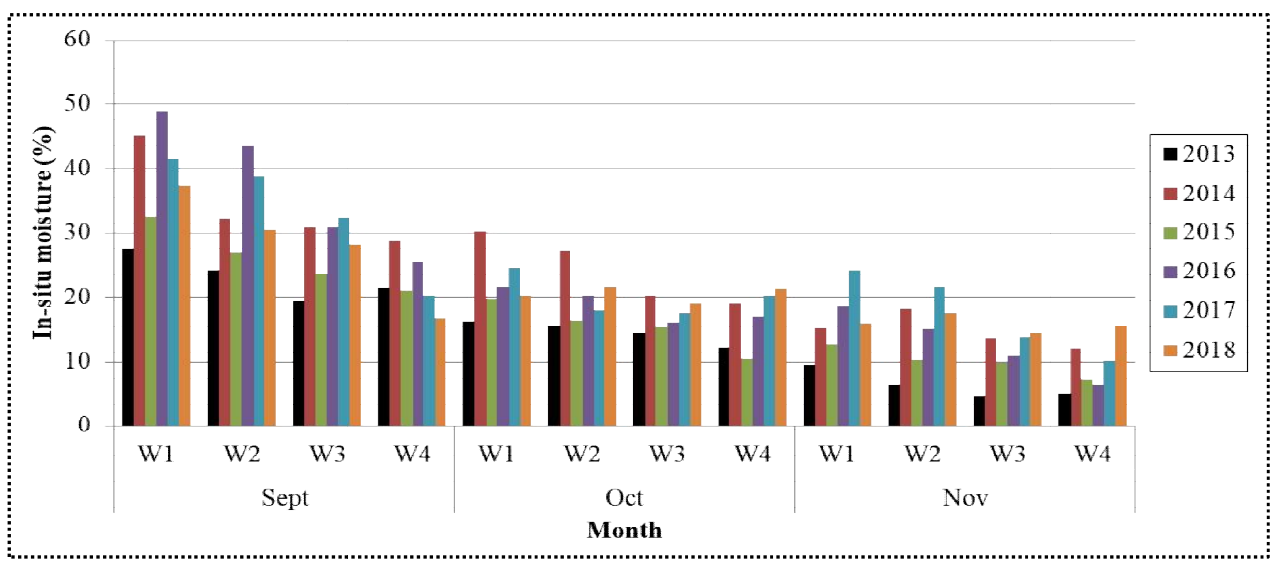

Figure 7. In-situ moisture distribution in soils (before and after the construction of road side pits in Gule area, Tigray, Ethiopia. Construction of the road side pits was done on May-June 2014. Monitoring was done for the period September-November for the years 2013 to 2016 (W1= Week one; W2=Week two; W3=Week three and W4=Week four). 


\subsubsection{Effects of Road Side Pits on Soil Moisture in Silty Clay Soil (MS6)}

To evaluate the moisture variations (before and after) of the interventions, monitoring was carried out in Adigudom area where the soil is dominantly silty clay type (MS6). Results of the monitoring (Fig 8a) show that the moisture content of the soils has improved by up to $70 \%$ after the intervention when compared to the same season before the intervention despite rainfall variability (Fig $8 b)$.

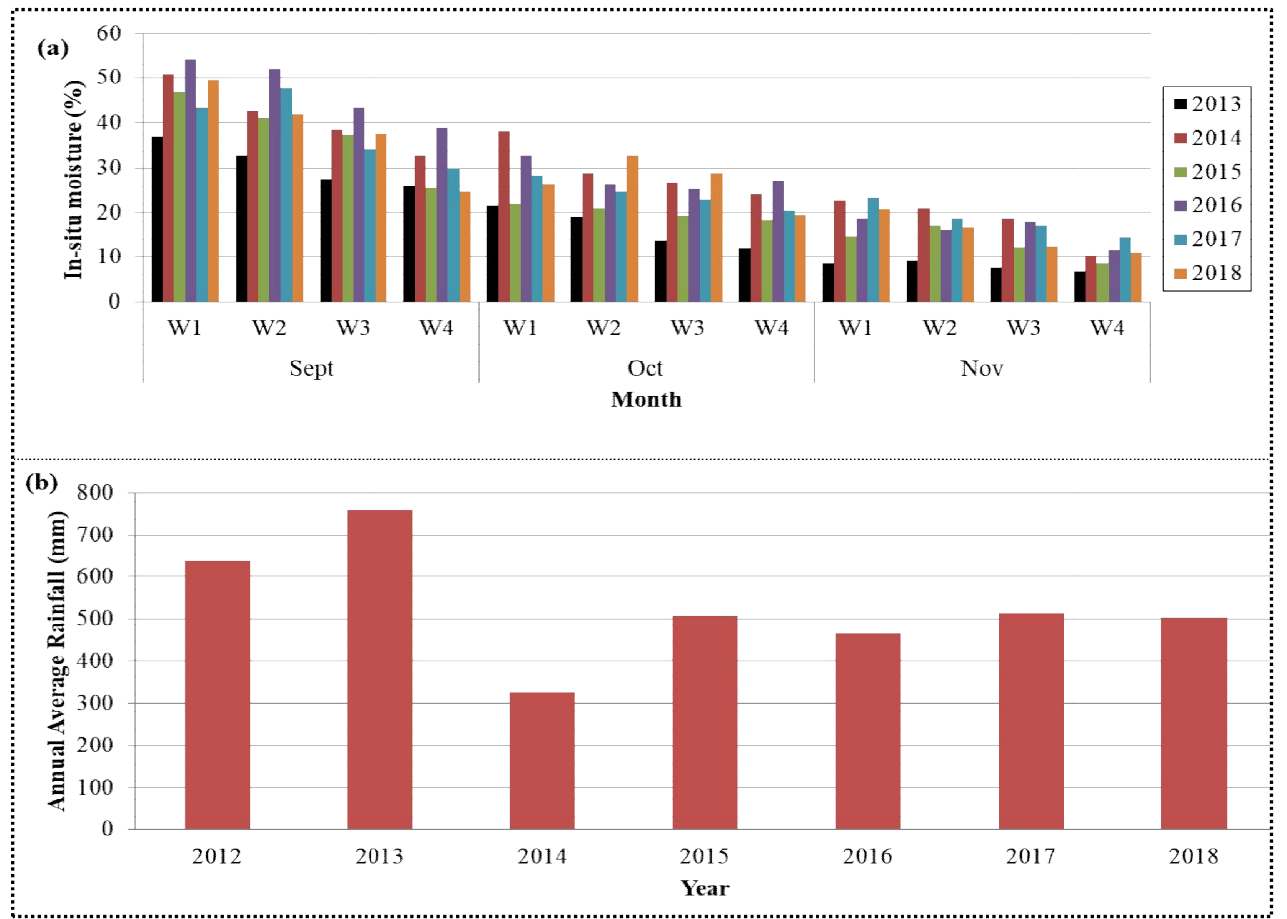

Figure 8. a) In-situ moisture distribution in soils (before and after the construction of road side pits in Adigudom area, Tigray, Ethiopia. Construction of the road side pits was done on May-June 2014. Monitoring was done for the period September-November for the years 2013 to 2016. (W1= Week one; W2=Week two; W3=Week three and W4=Week four); b) Rainfall distribution for Adigudom area for the year 2012 to 2018 (ENMSA, 2018).

\subsubsection{Effects of Storing Water from Culverts in Check-dam Ponds (MS7)}

Though check-dam construction is a common water harvesting and gully treatment technique in many parts of Tigray, systematically linking water from roads with check-dam ponds is a recent development (MS7). With the purpose of storing surface water from a culvert and enhancing groundwater recharge a check-dam pond was constructed in Selekleka area in the year 2014 (Plate 5a). Results of the groundwater level measurement (Fig 9a) shows that due to the storage of water from culverts in check-dam ponds, the shallow well which used to dry in the dry season has become very productive even during the worst drought period (El-Nino 
period of the year 2015). The groundwater level remained nearly remained the same despite rainfall variability over the years (Fig 9b) because of recharge from the check-dam pond.

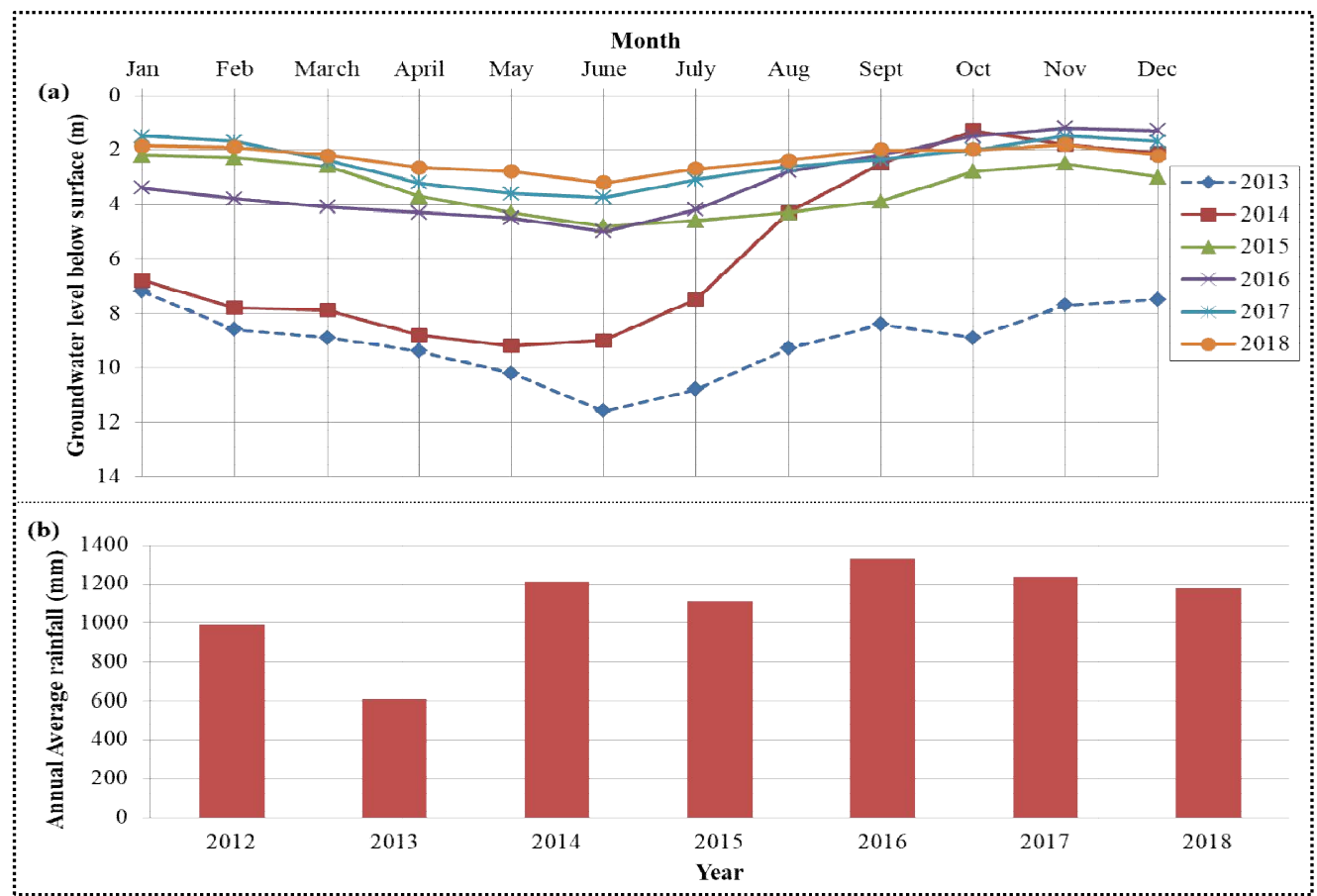

Figure 9. a) Groundwater fluctuation in Selekleka area, Tigray, Ethiopia (at downstream of a check-dam which was constructed in the period January-May, 2014). The check-dam is designed to store surface water from a box culvert. Groundwater level has improved at downstream of the box culvert after the construction of the check-dam, b) Rainfall distribution for Selekleka area for the year 2012 to 2018 (ENMSA, 2018).

\subsubsection{Effects of Channelling Water from Bridges to Series of Ponds (MS8)}

As part of the emergency efforts to address the worst droughts which took place in 2015/2016, the regional government of Tigray has implemented a massive water harvesting program including water from road catchments. Among the techniques implemented were constructions of large water storage ponds (with capacities ranging from $50 \mathrm{~m}^{3}$ to $12500 \mathrm{~m}^{3}$ ) whereby such structures are connected to culverts, roadside ditches and bridges (e.g. Plate 1a). Hydrological monitoring (MS8) on the performance of such interventions have shown multiple benefits: reduction in flooding at downstream areas of ponds, enhancing availability of surface water for livestock and household use (like washing), and recharge of groundwater. Especially the effect on shallow groundwater level at downstream of the ponds was very significant whereby static groundwater level has raised upto $2 \mathrm{~m}$ below surface (Fig 10) as a result of recharge from upstream ponds. 


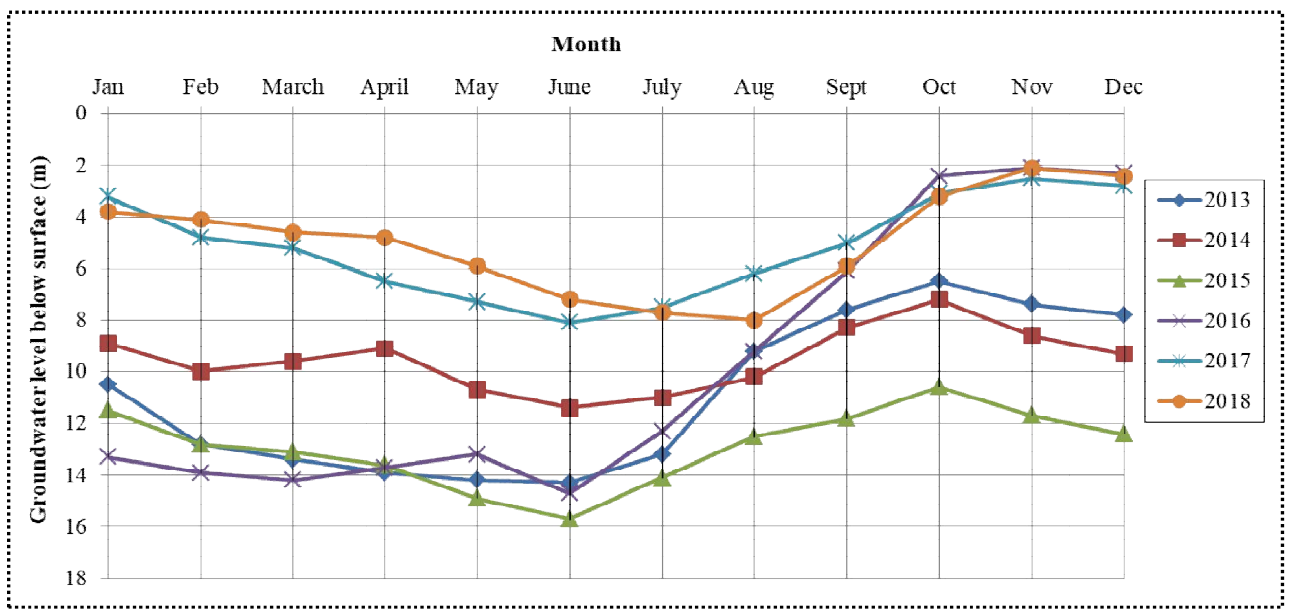

Figure 10. Groundwater fluctuation in Adigudom area, Tigray, Ethiopia (at downstream of series of water storage ponds) which were constructed in the period December to January 2015 as part of the emergency program to address drought. This resulted in raise in groundwater level to a depth of about $2 \mathrm{~m}$ below surface in the year 2018 due to such interventions.

\subsection{Scenarios for Promoting Road Water Management}

The RWH practice in Tigray has been implemented in collaboration with different sectors (water, agriculture, roads, environment) and partners (government, non-government and local communities). From the experience so far, three scenarios are suggested to upscale and promote road water harvesting/management at scale:

- Using existing roads to harvest/manage water: This is to connect road hydraulic systems/structures with potential sites for water harvesting/management using suitable technology. Factors considered in the selection of appropriate water harvesting technology include: (i) soil/rock properties (type, thickness, hydraulic characteristics), (ii) slope angle, (iii) rainfall (intensity, amount), (iv) catchment area, and (v) water level and water demand. In this option, it is necessary to consider any negative effects to the road reserve or to any other facilities.

- Design modification (during road maintenance) to integrate water harvesting: This is done during maintenance/ upgrading in order to accommodate water harvesting/ management. One of the challenges, during and/or after road construction is contractual issues among client, contractor and consultant. It is important to allow some design modification to accommodate water harvesting with minimum cost variations, especially in areas with critical shortage of water. For example, i) borrow pits as water storage structures as it is common to have such pits along roads; ii) looking into options of connecting road hydraulic structures (culverts, bridges, roadside ditches, etc) with borrow pits or other water 
storages during upgrading of roads. If cost allows, during road upgrading/maintenance, options of relocating culverts and other hydraulic structures could be considered to connect water from road catchments into suitable locations of road water harvesting structures.

- Road water harvesting as part of road design and construction procedure: During road development planning it is important to note how water from a road (drains, culverts, bridges, fords, road surface) could be harvested for the benefit of the local community. This is to make road water harvesting as part of the design and construction procedures using standard guidelines. This could include consideration of road water management/harvesting during road route selection, borrow pit site selection, locating road hydraulic structures (culverts, roadside ditches, bridges, etc), and design of road crossings to buffer water. In suitable locations, road embankments could also be designed to act as water storage dams. The location, type and size of road hydraulic structures and in some cases the entire alignment of the road could be designed with the objective of harvesting water from roads collected into surface water reservoirs or used for groundwater recharge. This requires an understanding and evaluation of hydrology and geotechnical aspects of the sites.

\subsection{Towards Landscape Continuum Approach of Road and Water Development}

Many roads in Tigray pass through mountainous terrains where unmanned water from roads causes number of problems like gully erosion, flooding, and even landslides. Similarly, runoff water from upslopes of roads could cause flooding, siltations and erosions of roads. Understanding the interaction among landscapes, roads and water is critical for ensuring safety of the infrastructures and optimizing other benefits through proper management.

The research done in northern Ethiopia has demonstrated the importance of road development in landscape continuum approach: (a) reducing runoff and enhancing infiltration at upslope areas, (b) integration of water management in the road reserve and road hydraulic systems, and (c) reducing any negative effects and enhancing water management in the down slope areas (e.g. Plate 12).

In the design and constructions of infrastructures, it is advisable to consider the landscapes as a continuum. A generalized landscape model is presented that shows the different techniques which could be considered in different parts of the landscapes (Fig 11): (a) upslope of roads: reduce flooding of downstream areas (including roads) through enhanced infiltration and avoid initiations of landslides, (b) road section/reserve: promote water buffering and enhance water harvesting by protecting the safety of the road, and (c) downslope of roads: reduce the negative effects of water from roads and enhance water management. 

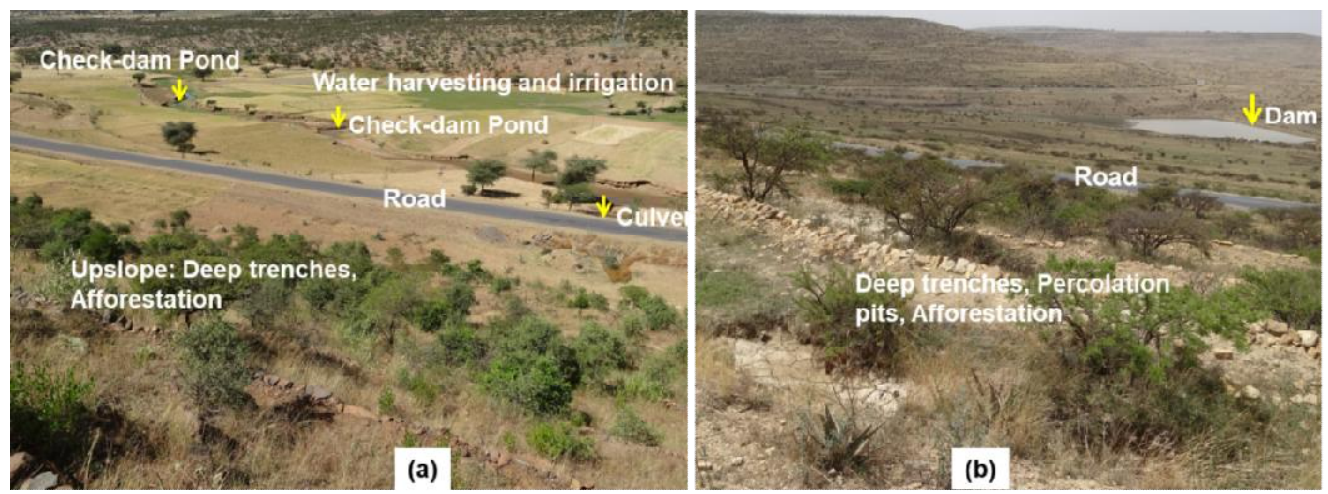

Plate 12. Example of a landscape continuum based land-water and infrastructure developments in Tigray, Ethiopia: (a) water from roads harvesting in check-dam ponds groundwater recharge and irrigation, (b) dam is saved from siltation due to land management at upslope and downslope of the road.

\begin{tabular}{|c|c|c|}
\hline Upstream/Upslope & Road Section & Downstream/Downslope \\
\hline 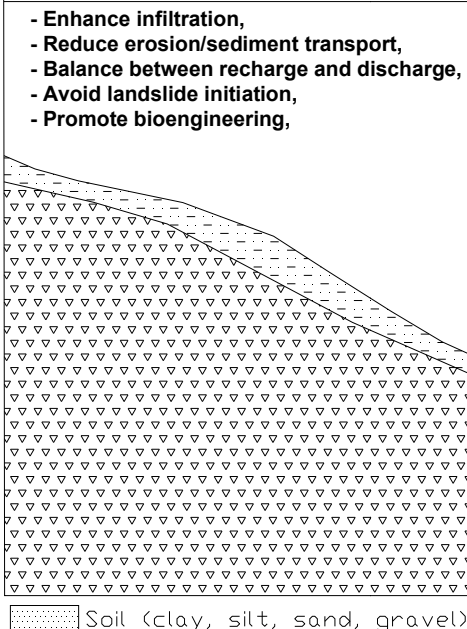 & $\begin{array}{l}\text { - Roads as dam } \\
\text { embankments, } \\
\text { - Water buffering } \\
\text { crossings, } \\
\text { - Road hydraulic } \\
\text { systems as water } \\
\text { conveyance, } \\
\text { - Stable slope and } \\
\text { subgrade, } \\
\text { - Avoid erosion, } \\
\text { - Promote } \\
\text { bioengineering } \\
\text { Road }\end{array}$ & $\begin{array}{l}\text { - Reduce downstream flooding, } \\
\text { - Reduce downstream erosion, } \\
\text { - Enhance groundwater recharge, } \\
\text { - Enhance soil moisture, } \\
\text { - Avoid/minimize road damages, } \\
\text { - Avoid landslide initiations, } \\
\text { - Promote bioengineering, } \\
\text { - Promote water harvesting/management, } \\
\text { - Enhance sustainable use of water } \\
\text { (water supply, irrigation, etc). }\end{array}$ \\
\hline
\end{tabular}

Figure 11. Typical model and design considerations for the development of roads in hilly areas with landscape continuum water management concept.

\section{CONCLUSIONS}

The following conclusions are drawn from this research:

- Managing water from roads and road catchment (using different techniques) is found to have multiple benefits: (a) enhance soil moisture and groundwater recharge, (b) increase availability of surface water for multiple use, (c) reduce flooding and erosion at downstream areas, and (d) increase the resilience of local communities to droughts and rainfall variability.

- The factors which need to be considered in the design of RWH structures include: (a) rainfall (amount and intensity), catchment characteristics (size, slope angle, vegetation 
cover, and management practices), slope angle of the site, permeability/infiltration capacity of the soil/rock, and water demand.

- For water harvesting from roads to be implemented more effectively there should be strong linkages and cooperation among the sectors through a more powerful body but with clear tasks and responsibilities for each stakeholder. There is a need to include road side communities in the design and implementation of the road and water programs and also to regulate access to the new water resources generated for male and female community members.

- The lessons learned from the research work in northern Ethiopia have been remarkable: road development could offer a lot of opportunities for water management especially in areas with shortage of water. In the design and constructions of roads, it is critical to assess the landscape-road-water interactions and design appropriate solutions on landscape continuum based approach that: (a) reduces damage on the roads and on the landscapes, and (b) enhances livelihood improvements and environmental benefits.

\section{ACKNOWLEDGEMENTS}

The authors would like to acknowledge the following organizations for their financial support for this research: (a) NWO/WOTRO (Netherlands Scientific Council), (b) Global Resilience Program (GRP), and (c) UPGro (NERC). All collaborating institutions for this research are duly appreciated for their support, mainly: (i) Tigray Bureau of Water Resources, (ii) Tigray Bureau of Transport, Road and Construction, (iii) Tigray Bureau of Agriculture and Rural Development, and (iv) Relief Society of Tigray, and Wukro Saint Mary College.The authors would like to thank the anonymous reviewers of this paper. Prof. K. Bheemalingeswara, from School of Earth Science at Mekelle University, is highly acknowledged for his relentless support and encouragement.

\section{CONFLICT OF INTERESTS}

There are no conflicts of interest.

\section{REFERENCE}

Berhane, G., Gebreyohannes, T., Martens, K \& Walraevens, K. 2016. Overview of microdam reservoirs (MDR) in Tigray (northern Ethiopia): Challenges and benefits. $J$. African Earth Sciences, 123: 210-222, http://dx.doi.org/10.1016/j.jafrearsci.2016.07.022. 
Biggs, J., Williams, P., Whitfield, M., Nicolet, P., Brown, C., Hollis, J., Arnold, D \& Pepper, T. 2007. The freshwater biota of British agricultural landscapes and their sensitivity to pesticides. Agriculture Ecosystems \& Environment, 122: 137-148.

BMZ, GiZ \& KfW. 2012. Water-spreading Weirs for the Development of Degraded River Valleys: Experience from the Sahel, Eschborn: GIZ.

Bouma, J.A., Biggs T.W \& Bauwer L.M. 2011. The downstream externalities of harvesting rainwater in semi-arid watersheds: An Indian case study. Agricultural Water Management, 8(7): 1162-1170, doi:10.1016/j.agwat.2011.02.010.

Bryceson, D.B., Bradbury, A \& Bradbury, T. 2008. Roads to poverty reduction? Exploring rural roads' impact on mobility in Africa and Asia. Development Policy Review, 26(4): 459-84, <http://dx.doi.org/10.1111/j.1467-7679.2008.00418.x>.

Collinson, N. H., Biggs, J., Corfield, A., Hodson, M.J., Walker, D., Whitfield, M \& Williams, P. J. 1995. Temporary and permanent ponds - an assessment of the effects of drying out on the conservation value of aquatic macro-invertebrate communities. Biological Conservation, 74: 125-134, https://doi.org/10.1016/0006-3207(95)00021-U.

Crawford, E., Kelly, V., Jayne, T.S \& Howard, J. 2003. Input use and market development in Sub-Saharan Africa: an overview. Food Policy, 28: 277-292, <http://dx.doi.org/ 10.1016/ j.foodpol.2003.08.003>.

De Grassi, A. 2005. Transport, poverty and agrarian change in Africa: models, mechanisms and new ways forward. IDS Bulletin, 36(2): 52-7, <http://dx.doi.org/ 10.1111/j.17595436.2005.tb00196.x>.

Demenge, J. 2011. Living on the Road, Waiting for the Road: The Political Ecology of Road Construction in Ladakh [online]. Brighton: Institute of Development Studies, University of Sussex, <http://sro.sussex.ac.uk/id/eprint/38501> [accessed 26-3-2014].

Demenge, J., Alba, R., Welle, K., Woldearegay, K., Manjur, K., Addisu, A \& Mehta, L. 2015. Multifunctional Roads: The Potential Effects of Combined Roads and Water Harvesting Infrastructure on Livelihoods and Poverty. Ethiopia J. Infrastructure Development, 7(2): 165-180, doi: 10.1177/0974930615609482, http://joi.sagepub.com.

EGS (Ethiopian Geological Survey) 2002. Hydrogeological Map of Northern Ethiopia. Addis Ababa.

ECSA (Ethiopian Central Statistics Agency)2007. Census data for Ethiopia. Addis Ababa.

ENMSA (Ethiopian National Meteorology Service Agency) 2018. Rainfall data of Tigray region for the years 2010 to 2018. Addis Ababa, Ethiopia. 
Ericson, M. 2008. Policy perspectives of road traffic injury in developing Asia. $17^{\text {th }}$ Biennial Conference of the Asian Studies Association of Australia [pdf], Melbourne: Monash University <http://artsonline.monash.edu.au/mai/files/2012/07/matthewericson.pdf>.

Fishbein, R. 2001. Rural infrastructure in Africa: policy directions. Africa Regional Working Paper Series 18, Washington DC, World Bank, www.worldbank.org/afr/wps/wp18.pdf.

Garcia-Landarte Puertas, D., Woldearegay, K., Mehta, L., Beusekom, M., Agujetas, M \& van Steenbergen, F. 2014. Roads for water: the unused potential. Waterlines, 33: 120-138.

Grum, B., Woldearegay, K., Hessel, R., Baartman, J.E.M., Abdulkadir, M., Yazew, E., Kessler, A., Ritsema, C.J \& Geissen V. 2017. Assessing the effect of water harvesting techniques on event-based hydrological responses and sediment yield at a catchment scale in northern Ethiopia using the Limburg Soil Erosion Model (LISEM). Catena, 159: 20-34, http://dx.doi.org/10.1016/j.catena.2017.07.018.

Hatibu, N., Mahoo, H. F \& Kajiru, G.J. 2000. The role of RWH in agriculture and natural resources management: from mitigating droughts to preventing floods. In: Rainwater Harvesting for Natural Resources Management. In: N. Hatibu, and H. F. Mahoo (eds), A planning guide for Tanzania. RELMA, Nairobi, Technical Handbook 22: 58-83.

IFPRI (International Food Policy Research Institute) 2005. Infrastructure development and poverty reduction: a literature review. In: S. Fan and C. Chan-Kang (eds), Road Development, Economic Growth and Poverty Reduction in China, IFPRI, Washington, DC, pp. 22-8.

Kubbinga, B. 2012. Road Runoff Harvesting in the Drylands of Sub-Saharan Africa: Its Potential for Assisting Smallholder Farmers in Coping with Water Scarcity and Climate Change, Based on Case Studies in Eastern Province, Kenya. MSc thesis, Amsterdam: Vrije University (unpubl.).

Mahapa, S.M \& Mashiri, M. 2001. Social exclusion and rural transport: gender aspects of a road improvement project in Tshitwe, Northern Province. Development Southern Africa, 18(3): 365-76, <http://dx.doi.org/10.1080/03768350120070026>.

Mishra, A., Froebrich, J \& Gassman, P.W. 2007. Evaluation of the SWAT model for assessing sediment control structures in a small watershed in India. Transactions of the American Society of Agricultural and Biological Engineers, 50(2): 469-477.

Morgan, R.P.C. 2005. Soil erosion and conservation. $3^{\text {rd }}$ edition. Blackwell Publishing Ltd.

MWE (Ministry of Water and Energy). 2012. Performance Report of the Ministry of Water and Energy for the year 2011/2012. Addis Ababa, Ethiopia. 78p. 
Neal, I. 2012. The potential of sand dam road crossings. Dams and Reservoirs, 22(3/4): 129143, <http://dx.doi.org/10.1680/dare.13.00004>.

Ngigi, S.N. 2003. Rainwater Harvesting for Improved Food Security: Promising Technologies in the Greater Horn of Africa Nairobi, Kenya: Greater Horn of Africa Rainwater Partnership (GHARP).Kenya Rainwater Association (KRA), 266p.

Nissen-Petersen, E. 2006. Water from Roads: A Handbook for Technicians and Farmers on Harvesting Rain Water from Roads, Nairobi: ASAL Consultants Ltd, 45p.

Nyssen, J., Poessen, J., Moeyersons, J., Luyten, E., Veyret-Picot, M., Deckers, J., Haile, M \& Govers, G. 2002. Impact of Road Building on Gully Erosion Risk: A Case Study from The Northern Ethiopian Highlands. Earth surface processes and Landforms, 27: 1267-1283.

Polyakov, V.O., Nichols, M.H., McClaran, M.P \& Nearing, M.A. 2014. Effect of check dams on runoff, sediment yield and retention on small semiarid watersheds. Journal of Soil and Water Conservation. 69(5): 414-421, doi:10.2489/jswc.69.5.414.

Pomfret, R. 2006. The Central Asian Economies since Independence, Princeton, NJ: Princeton University Press, https://press.princeton.edu/titles/8279.html.

Pond Conservation Group. 1993. A Future for Britain's Ponds: An Agenda for Action. Pond Conservation Group, Oxford. 35pp.

Riverson, J., Gaviria, J \& Thriscutt, S. 1991. Rural roads in sub-Saharan Africa: lessons from World Bank experience. World Bank technical paper no.WTP 141, World Bank, Washington DC; http://documents.worldbank.org/curated/en/128471468204559918/ Rural-roads-in-sub-Saharan-Africa-lessons-from-World-Bank-experience.

Tamene, L., Park, S.J., Dikau, R \& Vlek, P.L.G. 2006. Reservoir siltation in the semi-arid highlands of northern Ethiopia: sediment yield-catchment area relationship and a semi-quantitative approach for predicting sediment yield. Earth Surface Processes and Landforms, 31: 1364-1383, https://doi.org/10.1002/esp.1338.

TBoARD (Tigray Bureau of Agriculture and Rural Development). 2000. Performance Report of the Bureau for the year 1999-2000, Mekelle, 36p (unpubl.).

TBoARD (Tigray Bureau of Agriculture and Rural Development). 2008. Performance Report of the Bureau for the year 2007-2001, Mekelle, 28p (unpubl.).

TBoARD (Tigray Bureau of Agriculture and Rural Development). 2012. Performance Report of the Bureau for the year 2011-2012, Mekelle, 42p (unpubl.).

Van Steenbergen, F., Woldearegay, K., Agujetas, P. M., Manjur, K \& Abdullah, Al-Abyadh. M. 2018. Roads: Instruments for Rainwater Harvesting, Food Security and Climate 
Resilience in Arid and Semi-arid Areas. In: W. L. Filho and J. de Trincheria Gomez (eds.), Rainwater-Smart Agriculture in Arid and Semi-Arid Areas, Springer, pp.121144, https://doi.org/10.1007/978-3-319-66239-8_7.

Venables, A.J \& Limao, N. 1999. Infrastructure, geographical disadvantage and transport costs. Policy Research Working Paper Series 2257, World Bank, Washington, DC.

Villholth, K.G. 2013. Groundwater irrigation for smallholders in Sub-Saharan Africa- a synthesis of current knowledge to guide sustainable outcomes. Water International, 38(4): 369-391. doi: http://dx.doi.org/10.1080/02508060.2013.821644.

Wilson, F. 2004. Towards a political economy of roads: experiences from Peru. Development and Change, 35(3): 525-546, <http://dx.doi.org/10.1111/j.1467-7660.2004.00364.x>.

Woldearegay K. 2005. Rainfall-triggered landslides in the northern highlands of Ethiopia: Characterization, GIS-based Prediction and Mitigation. PhD Thesis, Graz University of Technology, Austria.

Woldearegay, K. 2018. Geological and geotechnical challenges of road development in mountainous terrains; the case of Hiwane-Mehoni road, Ethiopia. Presented at national conference on Research Review Day, Mekelle University, Ethiopia (unpubl.).

Woldearegay, K., Behailu, M \& Tamene, L. 2006. Conjunctive use of surface and groundwater: a strategic option for water security in the northern highlands of Ethiopia. Proceedings, Highland 2006 Sym., Mekelle University, Ethiopia (unpubl.).

Woldearegay, K., Tamene, L., Mekonnen, K., Kizito, F \& Bossio, D. 2018. Fostering Food Security and Climate Resilience Through Integrated Landscape Restoration Practices and Rainwater Harvesting/Management in Arid and Semi-arid Areas of Ethiopia. In: W. Leal Filho and J. de Trincheria Gomez (eds.), Rainwater-Smart Agriculture for Food Security, Poverty Alleviation and Climate Resilience in Arid and Semi-Arid Regions. Springer, pp 37-57, https://doi.org/10.1007/978-3-319-66239-8_3.

Woldearegay, K \& Van Steenbergen, F 2015. Shallow groundwater irrigation in Tigray, Northern Ethiopia: Practices and Issues. In: G. Lollino et al. (eds.), Engineering Geology for Society and Territory, Springer, doi: 10.1007/978-3-319-09054-2_103.

Woldearegay, K., van Steenbergen, F., Agujetas, P. M., Grum B \& van Beusekom, M. 2015. Water harvesting from roads: climate resilience in Tigray, Ethiopia. Proc. IRF Europe \& Central Asia Regional Congress, Istanbul, https://www.researchgate.net/ publication/302590574_Water_harvesting_from_roads_climate_resilience_in_Tigray Ethiopia. 
World Bank. 1994. The World Bank Annual Report 1994 (English). Washington DC, World Bank. http://documents.worldbank.org/curated/en/567941468322429653/The-World Bank-annual-report-1994.

World Bank. 2013. World Development Indicators 2013. Washington DC, http://elibrary. worldbank.org/doi/book/10.1596/978-0-8213-9824-1 [accessed 1-4-2014]. 